\title{
Characterization of the use-wear and residues resulting from limestone working. Experimental approach to the parietal art of La Viña rock shelter (La Manzaneda, Asturias, Spain)
}

\author{
Cristina López-Tascón ${ }^{\mathrm{a}, *}$, Antonella Pedergnana ${ }^{\mathrm{b}}$, Andreu Ollé ${ }^{\mathrm{c}, \mathrm{d}}$, Marco de la Rasilla ${ }^{\mathrm{a}}$, \\ Carlos Mazo ${ }^{\mathrm{e}}$ \\ a Área de Prehistoria, Departamento de Historia, Facultad de Filosofía y Letras, Universidad de Oviedo, Calle Amparo Pedregal s/n, 33011, Oviedo, Spain \\ ${ }^{\mathrm{b}}$ TraCEr, Laboratory for Traceology and Controlled Experiments at MONREPOS Archaeological Research Centre and Museum for Human Behavioural Evolution, RGZM, \\ Schloss Monrepos, 56567, Neuwied, Germany \\ ${ }^{\mathrm{c}}$ IPHES, Institut Català de Paleoecologia Humana i Evolució Social, Zona Educacional 4, Campus Sescelades URV (Edifici W3), 43007, Tarragona, Spain \\ ${ }^{\mathrm{d}}$ Universitat Rovira i Virgili, Dept. d'Història i Història de L'Art, Av. Catalunya 35, 43002, Tarragona, Spain \\ ${ }^{\text {e }}$ Departamento de Ciencias de la Antigüedad, Área de Prehistoria, Universidad de Zaragoza, C/ Pedro Cerbuna 12, 50009, Zaragoza, Spain
}

\section{A R T I C L E I N F O}

\section{Keywords:}

Use-wear analysis

Limestone engravings

Flint and quartzite tools

Experimental collection

Nalón river

\begin{abstract}
A B S T R A C T
The Palaeolithic rock engravings that are located along the Nalón river basin in Northern Spain (central area of Asturias) have been studied from various perspectives (morphology, depth, style, manual range), but no use-wear studies on the stone tools used to produce such engravings have ever been undertaken. This paper aims to explore a new approach to this type of incisions based on use-wear analysis of experimental lithic tools used to engrave limestone blocks and slabs. Our results show that the use-wear traces generated by engraving limestone are welldeveloped and can be defined with specific criteria. The principal objective of this study was to provide the first experimental reference collection of use-wear resulting from engraving limestone using flint and quartzite experimental tools to compare with the traces that appear on tools in the archaeological record in contexts with parietal and portable art and, more specifically, to add a new approach to the multidisciplinary study of the La Viña rock shelter.
\end{abstract}

\section{Introduction}

Engraved rock art has often been studied from a formal perspective. Traditional interpretations have been mainly proposed by using both typological and stylistic approaches, by analysing the formal aspects, types of representations and by comparing motifs and techniques from different geographical locations and chronology (Sauvet, 2015).

Nevertheless, while some researchers have recently used digital imaging technologies like photogrammetry and 3D scanning (among others, Plisson and Zotkina, 2015; Rivero et al., 2019), issues regarding chronology remain unresolved.

Presently, engraved art motifs cannot be dated directly. Furthermore, in the abscence of carbonate crusts or fragments of paint covering the engravings, relative dates for engraved art cannot be ascertained either. In this case, the association between the lithic tools bearing usewear traces produced after engraving rock (Plisson, 2007) and the parietal engraved art could help to provide indirect dates for the art.

Only sporadically has use-wear analysis been applied on lithic tools excavated from archaeological sites displaying rock art (i.e., painting and engravings). Despite the incredible potential of functional analysis to detect tools used to produce engravings, there is a limited record of published research on this topic (Delluc et al., 1988; Plisson, 2005, 2009; Medina-Alcaide et al., 2013; Beyries and Cattin, 2015; Perales and Prieto, 2015).

Moreover, the available publications have always been focused on Palaeolithic and Mesolithic sites located in a restricted area comprising France, Spain and Portugal. Traceology, when applied to an assemblage retrieved from an archaeological site displaying rock art, has the potential to distinguish the tools employed in the production of art (Leroi-Gourhan and Allain, 1979) from the ones used in other daily activities and not directly related with the symbolic world (e.g., butchering, wood working, etc.) (Rios-Garaizar et al., 2015).

\footnotetext{
* Corresponding author.

E-mail address: c.lopeztascon@gmail.com (C. López-Tascón).
} 
However, despite this potential, engraving experiments have not been very frequent in recent years. The available studies have focused on specific features such as the hardness of the engraved rock, the different possible techniques to be employed, etc. (Beaune and Pinçon, 2001; Ripoll et al., 2007; Venditti et al., 2016). Furthermore, there are very few works that combine engraving experiments and use-wear analysis (Astruc, 2002; Plisson, 2007; Aubry et al., 2011; Aubry and Sampaio, 2012; Guéret and Bénard, 2017). In most of the published studies, the experimental variables are not well explained (e.g. Beaune and Pinçon, 2001; Fernández Rey et al., 2005). The number of strokes, which is a very important variable, is rarely given. For example, the engraved art of the Nalón river basin (Asturias, Spain) (Fortea, 2000-2001; González-Pumariega Solís et al., 2017a) or the Aurignacian art from Dordogne (Delluc and Delluc, 1978) is formed by strong deep grooves. This may indicate that the tools which were used for engraving should present very well-developed use-wear, as an indicator of prolonged use.

Furthermore, the use-wear traces specifically generated by stone working have not been thoroughly studied thus far. Use-wear analysts have generally not attempted to reproduce these types of traces when compiling their experimental collections. When present, the number of experimental tools used for stone working is always limited (Keeley, 1980; Cahen and Gysels, 1983; Plisson, 1985; Vaughan, 1985; Mansur-Franchomme, 1986; Gijn, 1989; Mazo Pérez, 1989; González Urquijo and Ibáñez Estévez, 1994; Clemente Conte, 1997; Astruc, 2002; Fernández-Marchena, 2013; Martín Lerma, 2015, Guéret and Bénard, 2017). Moreover, the majority of studies analysing these traces have considered flint, while only Clemente Conte (1997) incorporated quartzite, Fernández-Marchena (2013) rock crystal and Alvarez et al. (2001) basalt and obsidian. As such, in this paper we present a first set of experiments made with flint and quartzite, focused exclusively on stone engraving. Control of the experimental stages and changes in the rock surfaces allow characterization of the traces, which had not been given much attention in the previous experimental functional studies.

In summary, this study presents a traceological approach to analyse experimental tools used in the reproduction of parietal limestone engravings. Experimental results aim to answer technological and functional questions, for instance specific lithic chaînes opératoires devoted to artistic processes, whether involving devoted/specialised tools or not. In that way, another objective of this study is to evaluate the use of different typological tools with different angles in the reproduction of rock engravings. Furthermore, the procedures developed in this study could be applied to other lithic assemblages coming from archaeological contexts presenting evidence of rock art. Apart from contributing data regarding technological aspects related to those representations, it could also help to indirectly date the rock art panels, when no direct dates are available.

\section{La Viña rock shelter}

La Viña rock shelter is located in La Manzaneda, $9 \mathrm{~km}$ south of the city of Oviedo, in the middle basin of the Nalón river (central part of Asturias). The site is a $30 \mathrm{~m}$ long limestone rock shelter and has a surface area of approximately $225 \mathrm{~m}^{2}$. It is situated in a very high strategic position in the landscape, $\sim 100 \mathrm{~m}$ above the river and $292 \mathrm{~m}$ above sea level, so its viewshed is large, providing good control of the surrounding valley (Fortea, 1994; García et al., 2013; Fano et al., 2018) (Fig. 1).

The importance of La Viña lies in the lengthy stratigraphic and cultural sequence dated from the Middle to the Upper Palaeolithic, and on the set of pre-Magdalenian engravings because they have been directly related to specific archaeological layers (Fortea and Rodríguez, 2007; González-Pumariega Solís et al., 2014; González-Pumariega Solís et al., 2017b).

The rock shelter, facing S-SE, was discovered in 1978 (Gavelas, 1980). Javier Fortea directed the excavation campaigns from 1980 until 1996, within the Middle Nalón Research Project (Fortea, 1981, 1990, 1992, 1995, 1999 and 2005-2006). Two sectors of the site, distinguished as Central and Western, were excavated. These sectors were chosen because they displayed the highest concentration of parietal engravings and have two thick calcareous masses next to the wall of the shelter (T1 and T4) (Fig. 2A) that preserve remains of settlements subsequent to level IV, which forms the current floor (Santamaría et al., 2014).

The Central sector was excavated between lines 10 and 14 and is composed of a wide stratigraphy of Upper Palaeolithic: Stratum I (without cultural assignment), stratum II (Upper Magdalenian), strata III and IV (Middle Magdalenian), stratum V (Upper Solutrean), stratum VI (subdivided in VIa - phase previous to the Upper Solutrean; VIb Gravettian; VIc and VIc inf - Gravettian with Noailles burins), stratum VII (collapse of the overhang, sterile), stratum VII (Aurignacian), stratum IX (Early Aurignacian), stratum X (undetermined initial Upper Palaeolithic) and stratum XI (limestone bedrock). In this sector there are only two dates for the stratum IV ranging between $16,075 \pm 285$ to 15,986 \pm 223 cal BP (Fortea, 1995; Suárez Ferruelo, 2011; Duarte Matías and Rasilla Vives, 2020) (Fig. 2B).

The Western sector is located in lines 23 and 27 and presents a spectacular stratigraphy partially dated by radiocarbon, conventional and AMS (Santamaría et al., 2014; Wood et al., 2014): Strata I and II (without cultural assignment), stratum III (Magdalenian), stratum IV (Middle Magdalenian), stratum V (Upper Solutrean), stratum VI (Middle Solutrean), stratum VII (End of the Gravettian), stratum VIII (Gravettian with Noailles burins), stratum IX (Gravettian with Noailles burins), stratum X (Gravettian with Noailles burins), stratum XI (late Aurignacian), stratum XII (Aurignacian), stratum XIII (Early Aurignacian), stratum XIII inf (Proto-Aurignacian), stratum XIII basal (Mousterian), XIV (Mousterian), stratum XV/IA (Mousterian), stratum IB (Mousterian) and stratum RA (altered bedrock) (Fortea, 1995; Martínez Fernández and Rasilla Vives, 2012; Santamaría, 2012; Martínez Fernández, 2015).

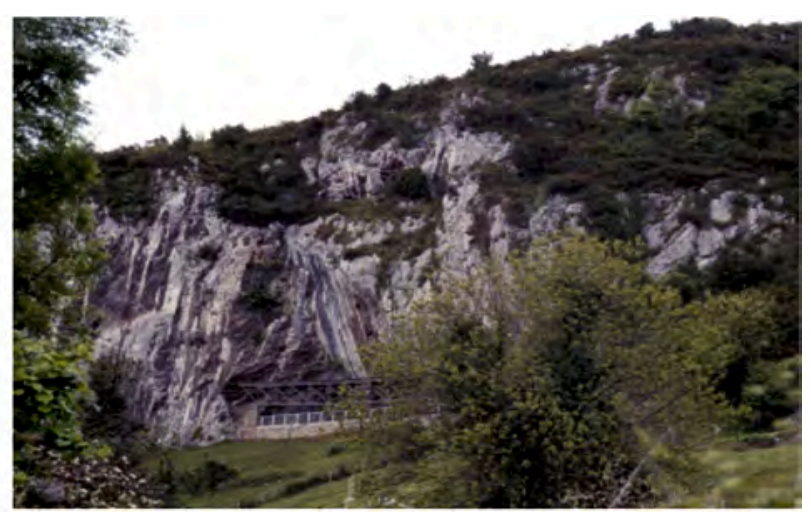

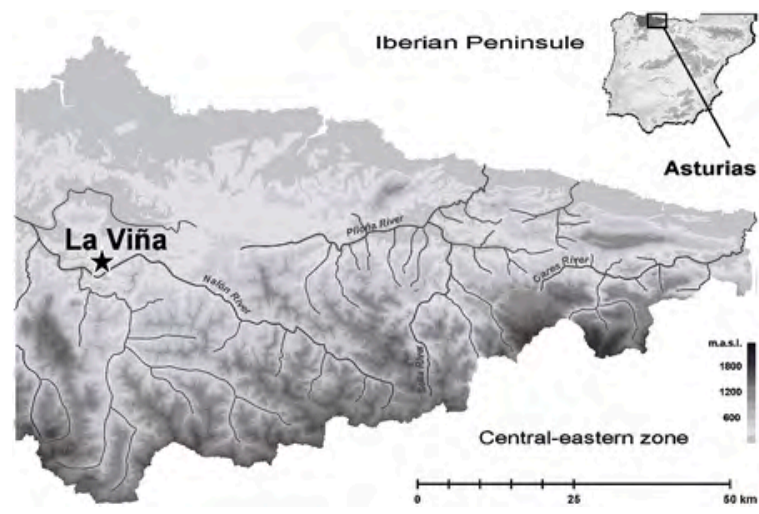

Fig. 1. La Viña location and general view. Map: E. Duarte. Photo: J. Fortea. 


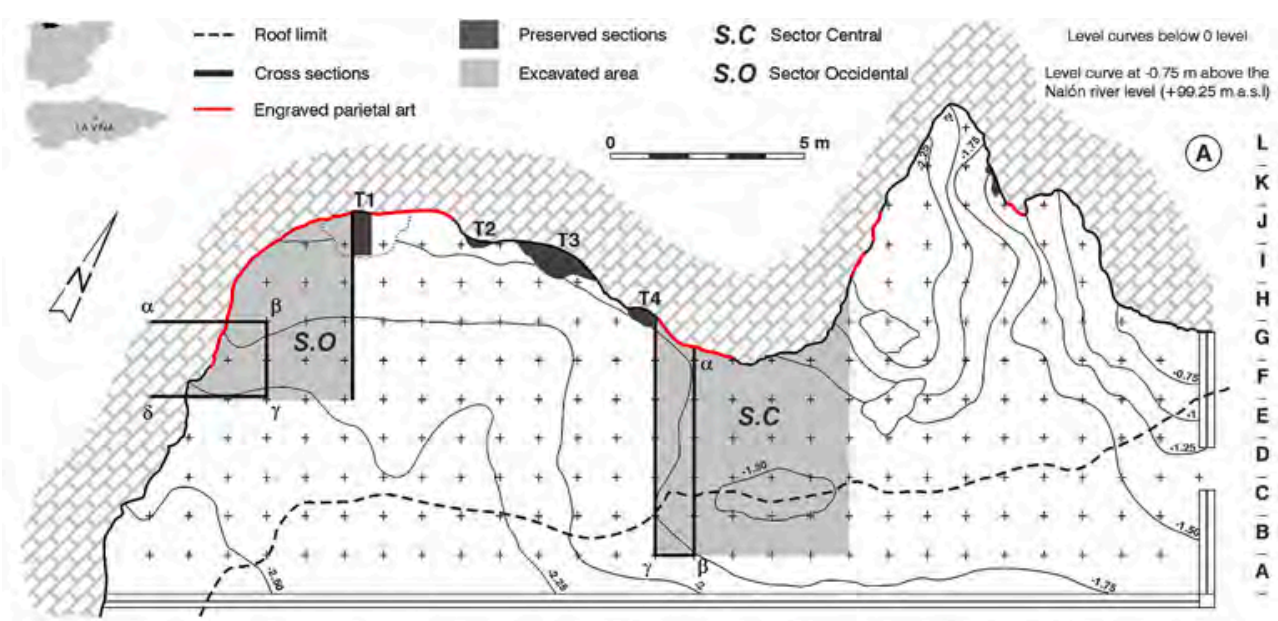

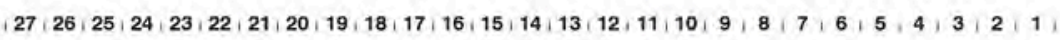
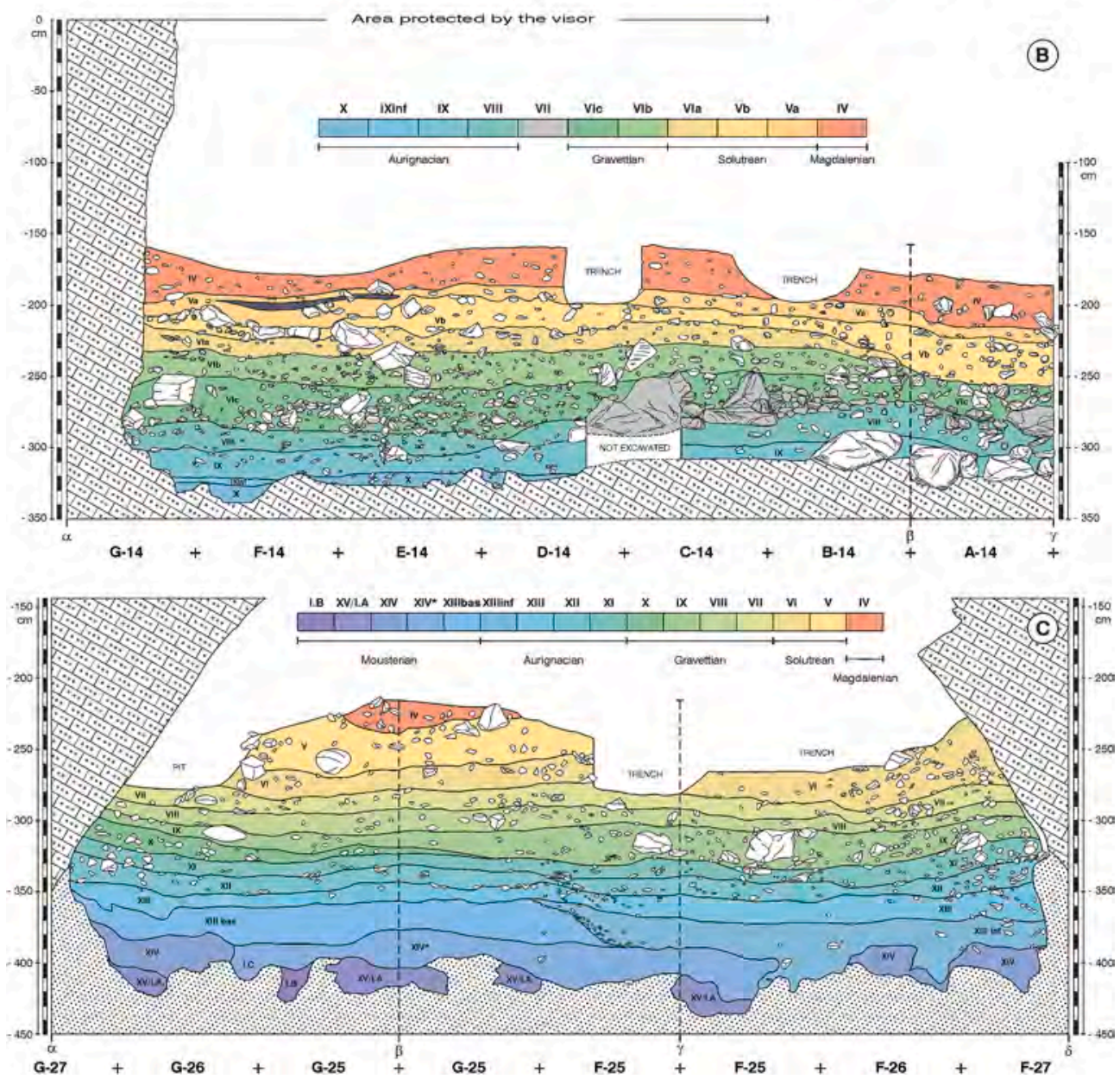

Fig. 2. A) Plan of the excavation of La Viña rock shelter. B) Stratigraphic section of the Central sector. C) Stratigraphic section of the Western sector.

The levels dated are IX, XI, XII, XIII, XIII inf, ranging from $62.000 \mathrm{BP}$ to 28,716 \pm 152 cal BP (Higham et al., 2014; Santamaría et al., 2014; Wood et al., 2014; Marín-Arroyo et al., 2018) (Fig. 2C).

The studies of archaeological materials have focused on the chronological and cultural context of MIS3 (Mousterian, Aurignacian and Gravettian levels). The techno-typological analysis of the Mousterian and Aurignacian levels of the WS (around 180.000 lithic artefacts that represent $\sim 60 \%$ of the total lithic remains of these levels) was carried out by D. Santamaría (2012) and the Gravettian levels of the same sector (a sample size of 15,912 lithic artefacts) by L. Martínez Fernández
(2015). The most frequent raw materials in various Middle and Upper Palaeolithic layers in both excavated sectors are quartzite and flint. The main rock in these levels is quartzite, although its percentages decrease as the cultural sequence progresses. The raw material sources are local $(<5 \mathrm{~km})$ for quartzite, and semi-local $(<10 \mathrm{~km})$ for the Piedramuelle flint. The human groups inhabiting the site used allochthonous raw materials like the Piloña flint variety, whose sources are located $\sim 40 \mathrm{~km}$ from the site, and Flysch flint variety located $\sim 120 \mathrm{~km}$ from La Viña (Suárez Ferruelo, 2011; Santamaría, 2012; Tarriño Vinagre et al., 2013; Martínez Fernández, 2015; Duarte Matías et al., 2016; Rasilla et al., 


\section{8, 2020).}

The ongoing studies of other archaeological materials from levels of MIS3 (fauna, charcoal and shells), reveal the lack of faunal remains due to erosive processes and the absence of shells in the Mousterian levels. In the Aurignacian levels, hominin activities can be recognized on bones due to the presence of burning damage and diagnostic elements of anthropogenic bone breakage. The red deer is exploited intensively, followed by chamois, horse, ibex and roe deer (Rasilla et al., 2018). Concerning archaeological shells, in Aurignacian and Gravettian levels, 65 mollusc shells belonging to 13 species of gastropods, bivalves and scaphopods have been detected. More than a third of the specimens show an anthropic perforation, and along with the presence of non-perforated shells, species without a bromatological value and specimens that were collected when they were already dead, suggest that they were used as ornamental beads (Martínez-Cuesta et al., 2018; Rasilla et al., 2018, 2020).

La Viña, together with twelve other open-air sites with rock engravings situated in the Nalón river basin, comprise the largest concentration of Palaeolithic engravings in the Cantabrian Region (Fortea and Rodríguez, 2007). Engravings of La Viña are present on the entire rock wall and are concentrated in four areas of the rock shelter, with the westernmost side (Zones IV and III) being the area with the highest concentration of engravings (Fig. 2A). There are two styles of art that have been defined by Fortea (1994) with the terms First and Second Graphical Horizons. The First Graphical Horizon is located on a lower level of the vertical wall plane and its graphical repertoire consists of a non-figurative set composed by linear, diagonal and vertical strokes, arranged in a regular and rhythmic way along the $12 \mathrm{~m}$ length of the wall. The length of these engravings ranges from 20 to $90 \mathrm{~cm}$, their width ranges from 1 to $2,5 \mathrm{~cm}$ and the deepest engravings are up to $2 \mathrm{~cm}$ deep. The Second Graphical Horizon is located above and superimposing the upper limit of some vertical strokes from the First Graphical Horizon. It is characterized by the representation of animals, with tri-lineal hinds being the most represented motif (Fig. 3), and a complicated framework of lines going in all directions that make it difficult to distinguish the various motifs on the panels. To date, the simultaneous presence of these two different types of engravings has only been documented at La Viña, so it must be considered a unicum (González-Pumariega, 2014; González-Pumariega Solís et al., 2017a, b. Another uncommon feature is that the engravings were partially covered by the Palaeolithic archaeological layers, an occurrence which is rarely observed (e.g., in Iberian peninsula Beltrán Martínez, 2002; Villaverde Bonilla, 2005; Fortea and Rasilla, 2000; Rasilla Vives et al., 2010; García Díez et al., 2012; Ripoll

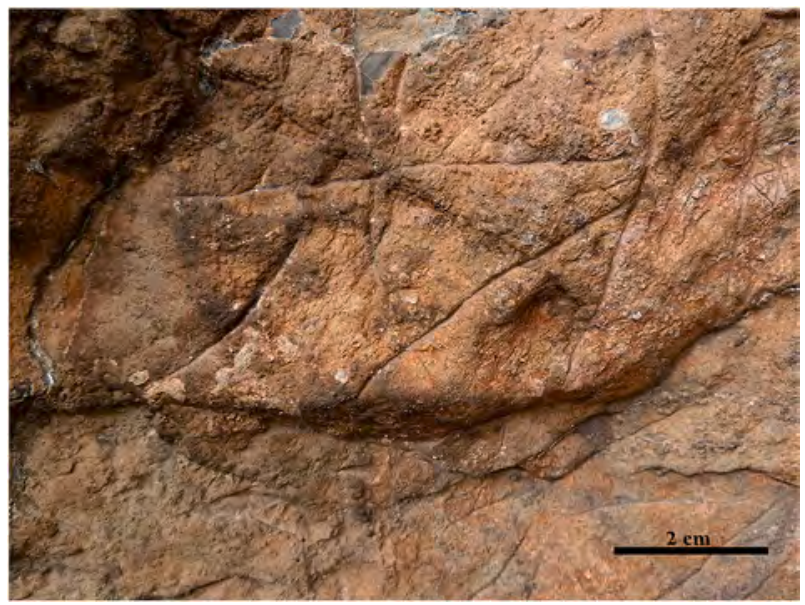

Fig. 3. Representation of a figurative engraving located in area IV for the Second Graphical Horizon. This is a schematic hind's head formed by three lines, which is a typical motif in the Palaeolithic art from the Cantabrian region (Photo by M. González-Pumariega).
López et al., 2012; Aubry et al., 2014). Information retrieved from the archaeological and stratigraphic contexts and the calculations for the manual range indicate that the termini ante quem for the Second Graphical Horizon is the Middle Magdalenian and the termini a quo are Gravettian and Solutrean periods. For the First Graphical Horizon the termini ante quem are Magdalenian, Solutrean and Final Gravettian, therefore the termini a quo is Recent Aurignacian and Gravettian (González-Pumariega Solís et al., 2017a, b).

\section{Material and methods}

\subsection{Experimental collection: raw material, flake production and} preparation of lithic pieces

Compiling an experimental reference collection is a condition sine qua non to be able to understand use-wear on the archaeological material (Semenov, 1964; Keeley, 1980; Plisson, 1985). The raw materials employed in our experimental programme are the same varieties that appear in the Middle and Upper Palaeolithic levels of La Viña rock shelter, Llonin cave, Cueto de la Mina rock shelter and Sidrón cave, all located in Asturias (Northern Spain). We used the most representative varieties of flint identified at La Viña, namely the Cenozoic flint Piedramuelle, and the Mesozoic flint Piloña. We also used a type of Carboniferous quartzite, which has been identified in the lithic assemblage of La Viña (Fortea et al., 2010; Santamaría, 2012; Tarriño Vinagre et al., 2013; Duarte Matías et al., 2016).

A total of 18 experiments were carried out by two experimenters, one of the authors (CL-T) and a construction worker not familiar with experimental archaeology (Table 1). All the experimental flakes were knapped and retouched by direct percussion using quartzite hammerstones. Different nodules were used for each of the three raw material varieties included. They were macro and microscopically documented before use. The activity performed was engraving limestone blocks, slabs and quarry walls. The longitudinal action was performed with either unidirectional or bidirectional movements and consistent pressure was applied for the entire duration of the activity (Mazo Pérez, 1991) (Fig. 4a, c).

Since burins have been frequently related to rock engraving (Leroi-Gourhan and Allain, 1979; Moure Romanillo and González Morales, 1988; Fortea and Rodríguez, 2007), three experiments were also performed by employing this typological tool. The burin bit ( 2 pieces) and the lateral edge ( 1 piece) were used. The other samples were all unretouched flakes, and the used portions of edges were rectilinear. This decision was made based on the techno-typology data provided by Santamaría (2012) and Martínez Fernández (2015), which shows that less than $23 \%$ of the retouched tools in the Mousterian, Aurignacian and Gravettian levels in the Western Sector of La Viña rock shelter are burins. Also, in these levels, the retouched material only represented less than $18 \%$ of the total number of lithic pieces of each level.

Additionally, four unretouched flint flakes were hafted (Wadley, 2005; Rots, 2010). We used two different materials for hafting: a wood stick and a deer antler (crown tine). The adhesive used for hafting was produced with birch wood resin, beeswax and charcoal without any additional reinforcement (Fig. 4b).

\subsection{Worked material}

Although in this paper we present only the experiments associated with stone working, our complete reference collection includes additional worked materials such as reeds, wood, bones, shells, etc. (López-Tascón et al., 2018a). The previously published data have allowed us to compare use-wear formed after contact with different worked materials with the results of the experiments discussed here.

The worked material selected in our experimental protocol is the same limestone variety of the La Viña rock shelter's walls. This sedimentary rock is traditionally called Caliza de Montaña (Mountain 
Table 1

Table with controlled variables in the experiments.

\begin{tabular}{|c|c|c|c|c|c|c|c|c|c|c|c|}
\hline $\begin{array}{l}\text { Reference } \\
\text { N. }\end{array}$ & Raw Material & Typology & $\begin{array}{l}\text { Dimensions } \\
(\mathrm{mm})\end{array}$ & Movement & $\begin{array}{l}\text { Active } \\
\text { Angle }\end{array}$ & $\begin{array}{l}\text { Active Edge } \\
(\mathrm{mm})\end{array}$ & Hafting & $\begin{array}{l}\text { Worked } \\
\text { limestone }\end{array}$ & Water & $\begin{array}{l}\text { Time } \\
(\min )\end{array}$ & Strokes \\
\hline Ex.Cal.001 & $\begin{array}{l}\text { Piedramuelle } \\
\text { Flint }\end{array}$ & Flake & $20 \times 26 \times 5$ & Bidirectional & 35 & 30 & Yes & Block & Yes & 60 & 1800 \\
\hline Ex.Cal.002 & $\begin{array}{l}\text { Piedramuelle } \\
\text { Flint }\end{array}$ & Flake & $27 \times 33 \times 13$ & Bidirectional & 40 & 70 & Yes & Block & Yes & 60 & 1800 \\
\hline Ex.Cal.003 & Piloña Flint & Flake & $34 \times 20 \times 7$ & Bidirectional & 45 & 30 & Yes & Block & Yes & 60 & 1800 \\
\hline Ex.Cal.004 & Piloña Flint & Flake & $31 \times 10 \times 7$ & Bidirectional & 45 & 50 & Yes & Slab & No & 60 & 1800 \\
\hline Ex.Cal.005 & $\begin{array}{l}\text { Piedramuelle } \\
\text { Flint }\end{array}$ & Burin & $30 \times 25 \times 6$ & Bidirectional & 30 & 60 & No & Slab & No & 120 & 2200 \\
\hline Ex.Cal.006 & $\begin{array}{l}\text { Piedramuelle } \\
\text { Flint }\end{array}$ & Burin & $27 \times 19 \times 6$ & Unidirectional & 30 & 65 & No & Slab & Yes & 120 & 1000 \\
\hline Ex.Cal.007 & $\begin{array}{l}\text { Piedramuelle } \\
\text { Flint }\end{array}$ & Burin & $35 \times 18 \times 7$ & Bidirectional & 45 & 70 & No & Block & Yes & 120 & 2150 \\
\hline Ex.Cal.008 & $\begin{array}{l}\text { Piedramuelle } \\
\text { Flint }\end{array}$ & Flake & $58 \times 36 \times 10$ & Bidirectional & 35 & 35 & No & Quarry's wall & No & 120 & 4500 \\
\hline Ex.Cal.009 & $\begin{array}{l}\text { Piedramuelle } \\
\text { Flint }\end{array}$ & Flake & $43 \times 29 \times 7$ & Bidirectional & 35 & 35 & No & Quarry's wall & No & 60 & 2300 \\
\hline Ex.Cal.010 & Piloña Flint & Flake & $22 \times 11 \times 4$ & Bidirectional & 40 & 35 & No & Slab & Yes & 60 & 2500 \\
\hline Ex.Cal.011 & Piloña Flint & Flake & $17 \times 23 \times 5$ & Bidirectional & 30 & 30 & No & Slab & No & 60 & 4000 \\
\hline Ex.Cal.012 & $\begin{array}{l}\text { Piedramuelle } \\
\text { Flint }\end{array}$ & Flake & $23 \times 17 \times 7$ & Unidirectional & 25 & 20 & No & Slab & No & 60 & 2000 \\
\hline Ex.Cal.013 & Quartzite & Flake & $68 \times 50 \times 18$ & Bidirectional & 35 & 30 & No & Slab & No & 120 & 4000 \\
\hline Ex.Cal.014 & Quartzite & Flake & $50 \times 39 \times 14$ & Unidirectional & 35 & 50 & No & Slab & No & 120 & 2000 \\
\hline Ex.Cal.015 & Quartzite & Flake & $41 \times 29 \times 9$ & Bidirectional & 30 & 60 & No & Slab & No & 120 & 4000 \\
\hline Ex.Cal.016 & Quartzite & Flake & $64 \times 65 \times 15$ & Unidirectional & 35 & 70 & No & Slab & No & 120 & 2000 \\
\hline Ex.Cal.017 & Quartzite & Flake & $61 \times 33 \times 9$ & Bidirectional & 35 & 25 & No & Slab & No & 60 & 2000 \\
\hline Ex.Cal.018 & Quartzite & Flake & $61 \times 38 \times 16$ & Unidirectional & 35 & 40 & No & Slab & Yes & 60 & 1000 \\
\hline
\end{tabular}
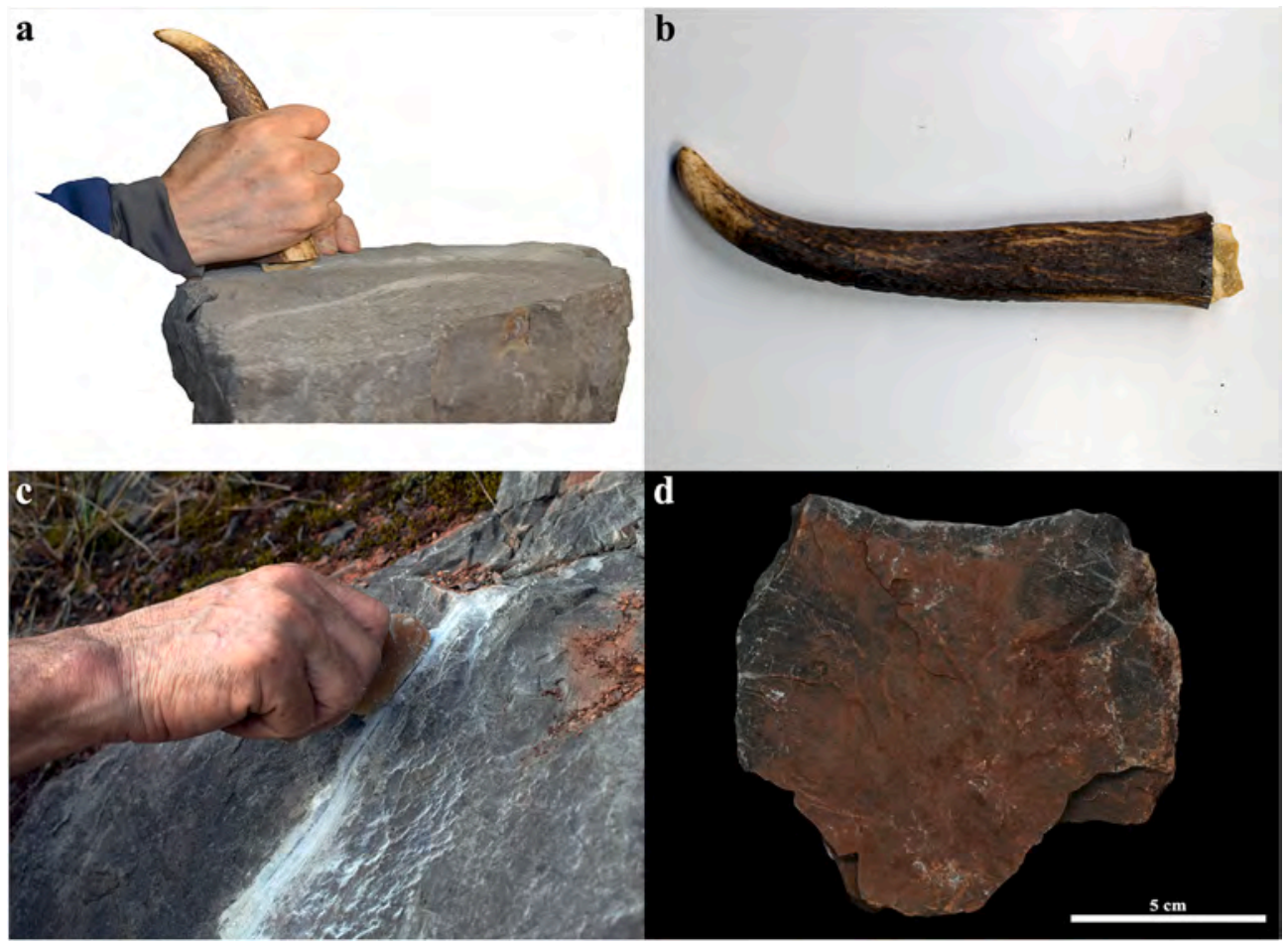

Fig. 4. Some examples of the experimentation. a) Engraving a limestone block with a hafted flint. b) Hafted flint in deer antler. c) Engraving limestone's quarry with a piece of flint. d) A slab of limestone used during experimentation. The colour red is the natural iron present in the quarry. (For interpretation of the references to colour in this figure legend, the reader is referred to the Web version of this article.)

Limestone) (Sánchez de la Torre et al., 1983:141), it is comprised of both Barcaliente Formation and Valdeteja Formation from the Visean-Namurian stage and it was formed in Carboniferous period. It is grey, thinly-bedded micritic and it has a poor fossil content. It releases a strong odour when broken or worked (Pérez-Estaún and Bea, 2004; Villa and Sánchez de Posada, 2009). The experiments were carried out both directly on the walls of an abandoned Mountain Limestone quarry near La
Viña rock shelter and on limestone slabs and blocks which were collected from the same quarry, selecting those presenting relatively flat surfaces (Fig. 4d). The dimensions of these detached blocks are variable, ranging from 25 to $40 \mathrm{~cm}$ in length, $20-35 \mathrm{~cm}$ in width and more than $15 \mathrm{~cm}$ in thickness. The slabs used are smaller, with dimensions ranging from 16 to $12 \mathrm{~cm}$ in length, from 15 to $10 \mathrm{~cm}$ in width and around $3,5 \mathrm{~cm}$ in thickness. 


\subsection{Experimentation}

Six quartzite flakes and twelve flint flakes (four: Piloña variety, eight: Piedramuelle variety) were used in the experiments. Three of the experiments with flint flakes were developed sequentially (Ollé and Vergès, 2014). The duration of each sequential experiment lasted $1 \mathrm{~h}$ (60 min), divided into sequential stages of use $(0,30,30 \mathrm{~min})$.

The engravings were produced by using a technique that applies direct pressure from the top to the bottom of the wall/block/slab. The direction of the movement was longitudinal and both uni- and bidirectional strokes were applied. The working angle were low $\left(25-45^{\circ}\right)$ and both dorsal and ventral faces of the pieces were in contact with the worked material (Fig. 4a and c). In other contexts, such as in the Côa Valley rock-art complex (Aubry et al., 2011) or at Church Hole (Ripoll et al., 2007) different experimental techniques to produce engravings have been proposed such as "piquetage" or light bas-relief. We did not consider those, as there was not any evidence that could be related to such techniques at La Viña site.

The linear engravings experimentally reproduced had lengths ranging between 10 and $15 \mathrm{~cm}$, with a width not exceeding $1.5 \mathrm{~cm}$. The depth of the grooves reached $1 \mathrm{~cm}$ in the deepest areas (Fig. 12e). Each groove was produced by using only one experimental flake and during the engraving process, on some occasions, water was added on the groove to facilitate the action.

\subsection{Post-experimental cleaning of samples and microscopic study}

Each tool was cleaned after use and documentation of residues. All pieces were cleaned with ultrasonic baths in neutral soap (Derquim ${ }^{\circledR}$ phosphate-free detergent), water and pure acetone $(\mathrm{CH} 3(\mathrm{CO}) \mathrm{CH} 3)$ in order to eliminate any type of residues (from the activity of engraving and from handling) (Ollé and Vergès, 2014; Fernández-Marchena and Ollé, 2016). For quartzite only, we used an acid solution ( $\mathrm{HCl}$ at $10 \%)$ to completely remove limestone residues that were found on the fissures of the samples after being previously cleaned.

The experimental pieces were analysed through a combined approach including low and high-power microscopes. The combination of both approaches is useful to obtain a more complete view of use-wear evidence. It is also essential to understand how macro-traces affect the development of micro-wear when hard materials, such as stone, are worked.

First, for lower magnifications, we used a stereomicroscope Nikon SMZ-10 with $10 \times$ ocular $(0,66-4 \mathrm{x})$ and a 3D digital microscope HIROX KH-8700, MXG-5000REZ (mainly Low-Range lens; 35-250 $\times$ ) to record macro-traces as scarring, rounding, and the general distribution of the polished surfaces.

After the first phase, we also used two reflected optical microscopes (OM) to document in detail micro use-wear traces as polish and striations: a Nikon Eclipse 50i and a Zeiss Axio Scope A1, both equipped with $5 \times$ to $50 \times$ lenses and $10 \times$ oculars.

Images were obtained with a Nikon (D90) camera. Series of multiple focus images were taken and processed with the Helicon Focus software, when necessary. In the case of the 3D digital microscope and the Zeiss microscope, their image capturing software includes a continuous multifocus system, so it was not necessary to use an external stacking software.

We have also employed a SEM (Scanning Electron Microscope) FEI Quanta 600 at low vacuum mode, equipped with an Oxford Instruments INCA system for digital image acquisition and treatment (Pedergnana and Ollé, 2017). These techniques (SEM and OM) have both advantages and disadvantages when imaging use-wear on stone tools (Borel et al., 2014), therefore their complementarity was essential in this study to describe traces originating from engraving limestone. In addition, the SEM microanalysis system (Energy-dispersive X-ray spectroscopy, EDX or EDS) was used to analyse the quartzite rock substrate and the elemental composition of residues.

\subsection{Use-wear traces identified}

The use-wear traces identified were divided into two groups. We documented macro-traces, mainly rounding and macro-scars. Rounding is caused by a loss of material in the active parts of the edges (Keeley, 1980; Anderson-Gerfaud, 1981; Gutiérrez Sáez, 1990; González Urquijo and Ibáñez Estévez, 1994). Macro-scars were described in terms of morphology, distribution, presence (unifacial or bifacial) and termination (Tringham et al., 1974; Odell and Odell-Vereecken, 1980; Jardón Giner, 1990).

The micro-traces documented comprised polish and striations. Polish is defined as a plastic modification which contrasts with the natural topography of rocks, generally being much brighter. Features, such as frame, distribution, morphology, contour and brightness of polished areas were documented. Finally, striations are defined as linear features with clear limits and are a good indicator of the kinematics of the actions (among others, Semenov, 1964; Keeley, 1980; Mansur-Franchomme, 1986; Plisson, 1985, Mazo Pérez, 1989; González Urquijo and Ibáñez Estévez, 1994).

\section{Results}

\subsection{Experimentation results}

The limestone used in the experiments appeared to be very hard. Even so, it was relatively easy to initiate a new linear trace on the limestone blocks/wall. The experimenter faced an increasing difficulty when continuing to exert pressure on the same groove. The tools had a tendency to slip away from the main groove and, as a consequence, they produced many shallow lines parallel to it (called parasite lines) (Aubry et al., 2011; López-Tascón et al., 2018b).

Flakes with longer edges were considered to be the most efficient ones by the experimenter, when compared to flakes with shorter edges. At the same time, we also observed that the efficiency of the flakes was determined by the angle of the active edge more than the type of raw material (flint vs. quartzite). The edges with sharper (i.e. acute) angles more easily broke when working limestone, especially in the first stages of the action (Alvarez et al., 2001). Moreover, the hafted pieces were the most efficient tools to engrave rock, because hafts allowed for better controlling the direction of the force applied.

Although no quantitative measurements were taken, we did not find any particular differences in the sections of the grooves produced with unretouched flakes with respect to those made with burins. The section morphologies seem to depend more on the original angles of the used tools. We observed that the engravings tend to have a $\mathrm{U}$ section when less acute angles are used, while pronounced acute angles generate grooves with V sections. Another aspect that we assessed is the time necessary to produce engravings on limestone. The duration of the experiments ranged from $\mathrm{ca}$. 30-60 $\mathrm{min}-120 \mathrm{~min}$ and in no case were we able to reproduce deep engravings such as those observed on the La Viña rock shelter's walls. While the experimental engravings do not exceed a length of $15 \mathrm{~cm}$ with a depth of $1 \mathrm{~cm}$, the deepest grooves from La Viña have a length between 40 and $90 \mathrm{~cm}$ with a depth of $2 \mathrm{~cm}$.

\subsection{Use-wear results}

The reference collection produced in this study includes the qualitative analysis of macro and micro traces and the documentation of residues resulting from working limestone blocks and slabs, paying special attention to microwear characteristic features. The results on quartzite and flint tools are preliminary.

\subsubsection{Macro-traces}

The macro traces analysed in this study were edge rounding and scars. Rounding is a wear feature usually related with different actions, such as hide scraping (Beyries, 2008) and plant processing (Mazzuco 
et al., 2015). It is also the principal and most characteristic attribute in working both hard and soft stones (Astruc, 2002; Guéret and Bénard, 2017). It appeared with high degrees of development in all our experimental tools, without pronounced differences between flint and quartzite. Although rounding is not a specific trait of stone working, heavy rounding can be visible with the naked eye on implements used to work limestone (Venditti et al., 2016) (Fig. 5). Edge rounding forms during the initial stages of activity and it progresses as long as the tools are used to engrave deeply into the limestone surface.

Scars are usually present on both faces of the active edges, although not in all tools. These are morphologically varied, being mainly trapezoidal, circular and semi-circular, and with both step and feather terminations. Macro-scars present differential distributions on flint and quartzite. Scars are either isolated or overlap with each other on flint tools, while they are always isolated on quartzite pieces. The high variability within this kind of macro-traces observed in this study for a single action leads us to believe that the traditional classification criteria present certain limitations for obtaining experimental comparable data.

On the one hand, continuous edge damage has not been observed on unretouched flakes, despite presenting rectilinear edges. On the other hand, burins present macro-scars on both ventral and dorsal surfaces and in facets edges close to the bit. The most frequent scar morphology observed on burins is the trapezoidal one. The number of scars on each face varies depending on the way in which the tools were held.

On the hafted tools, no macro scars were documented on the hafted section of the tools. It is possible that the adhesive used to glue the tools to the hafts absorbed the pressure generated during the engraving actions. It might also be that the tools were not moving in the hafts, therefore no scars were produced due to the contact with them.

One of the problems in analysing macro-scars exclusively, is that some of them disappear as edge rounding progress, so it is not a good criterion to identify stone working traces. Moreover, they can be produced by causes other than use, such as retouch, trampling and other post-depositional processes. For this reason, it is useful to do sequential experiments to document the development of scars after different timeintervals (Yamada, 1993; Pedergnana et al., 2017). In summary, we

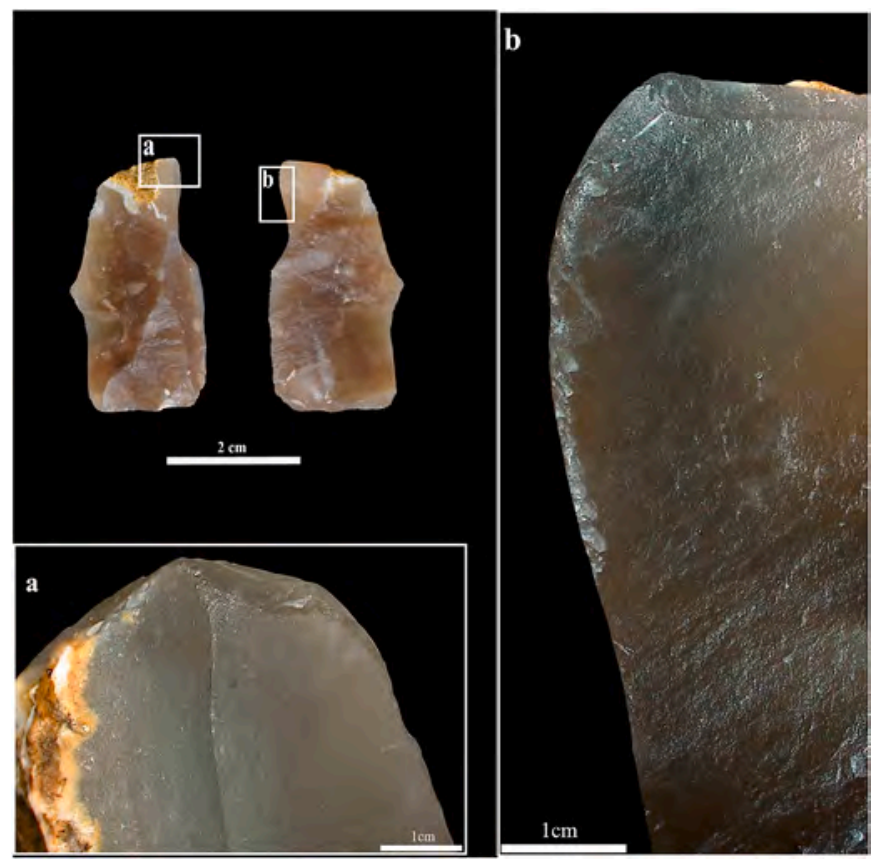

Fig. 5. Low magnification documentation of a flint experimental burin. a) Heavy edge rounding (Original mag. $35 \times$, digital microscopy micrograph). b) Ventral face with the micro-chipping near to the active part (Original mag. $35 \times$, digital microscopy micrograph). think that it would be very difficult to interpret this wear type in the archaeological record (Mazo Pérez, 1989).

\subsubsection{Micro-traces}

A clear phenomenon observed macroscopically during the experiments is that large portions of the edges broke when working limestone. As such, most of the microwear evidence formed during the initial stages is lost, remaining on the detached portions of the edge. The micro traces considered here comprises micro-polish, striations and micro rounding.

Polish concentrates on the rim, and is visible from both faces, but is not continuous. Its contour is clearly distinguishable from unpolished areas. Resulting surfaces present very flat topographies, compact patterns and a high brightness (Figs. 6 and 7); this fact is similar to that observed by Alvarez et al. (2001) in their experimental basalt tools. Polish produced by working limestone is extremely shinier than polished surfaces observed on tools used to work other materials (e.g., wood, hide, bone).

Numerous and irregular holes are observed on polished areas (Fig. 7 b3 and Fig. 8 a,b). These depressions are not circular, hence they cannot be considered as pits, described in the literature (Sussman, 1986, Clemente Conte and Gibaja Bao, 2009).

Well-developed polish appears heavily cracked (Fig. 6b), and presents several lines mainly being either perpendicular to the edge but also presenting chaotic distributions. In some cases, these lines connect the holes previously described. We documented the same edge portion on a flint tool used to engrave limestone with two microscopes. Firstly, we analysed the flint tool with an OM and then with a SEM. The analyses with SEM perspective allowed us to confirm that polish is composed of flat plates caused by significant abrasion (on high topography parts of micro-surface) (Fig. 7).

On quartzite, polish is present on the highest parts of the used edges and has a rough texture. It resembles in some aspects the polish formed after contact with abrasive worked materials such as hide (Pedergnana and Ollé, 2017). Some polished areas present a mixture of rough and smooth characteristics. Polish is very continuous on the edges and quite invasive (Fig. 9). Similar to polishes observed on flint, polished surfaces on quartzite display several lines that may indicate where cracks initiated due to the pressure exerted during the engraving actions (Fig. 10).

Additionally, we used Energy dispersive X-rays spectroscopy (EDX) to analyse the composition of the rock substrate. Analysis reveals that the experimental quartzite flakes contain Potassium (K) grains, which appear brighter when analysed with the back-scattered electron detector (Fig. 11a), when compared to the main components of the rock (silicon and oxygen). Different crystals have different topographies that are observable under the SEM. Quartz grains present a smooth texture with a several lines and irregular holes, while in the grains containing potassium have a very flat surface. If we compare the SEM and digital microscopy images (Fig. 11a and b), it is easy to see the grains containing potassium with striations that are parallel to each other, therefore they indicate the kinematics of the action (Fig. 11c and d). The use of Gigapixel images (Vergès and Morales, 2014; Fernández-Marchena et al., 2020) becomes in these cases a suitable strategy to discern these striations. This is illustrated in the Gigapixel-like image (Supplementary Fig. 1) corresponding to Fig. 11c and d, in which the distribution of several striations parallel to the edge are documented.

Surprisingly, we documented a few striations on some pieces, different from what is described in the literature (González Urquijo and Ibáñez Estévez, 1994; Clemente Conte, 1997). Striations are parallel to the active edge, as is usual in longitudinal actions. They are large, deep and usually isolated (Fig. 6b and c).

On SEM images, undulated linear features are visible (Fig. 7a2 and a3). These soft depressions are located on polished surfaces and are parallel to the active edge, therefore they could also indicate the kinematics of the action.

Similarly, in that no macro-wear was documented on hafted pieces, no micro-wear features have been observed on the hafted parts. 


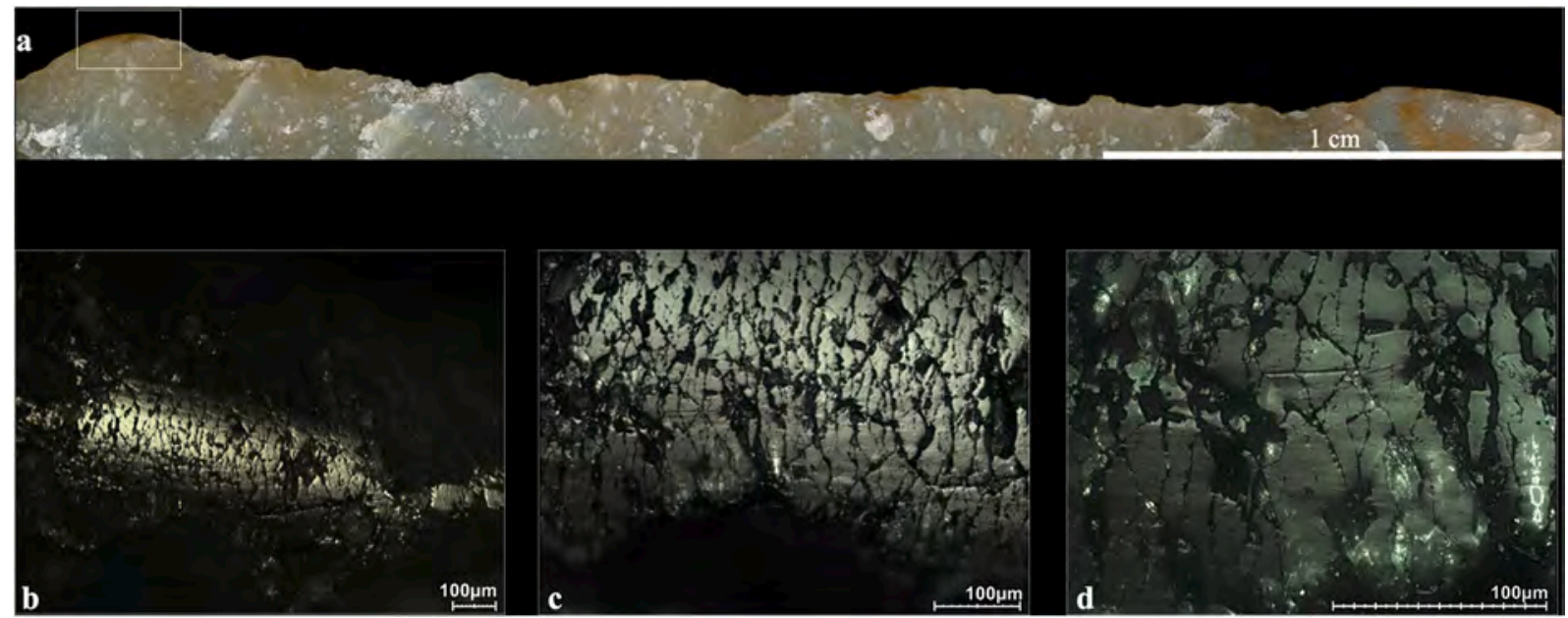

Fig. 6. The working edge of a flint tool after use 120 min: (a) mosaic of the worked edge at $50 \times$ of digital microscopy; b, c \& d show a well-developed cracked micropolish with chaotic perpendicular linear features to the edge made respectively by the lenses $10 \times, 20 \times$ and $50 \times$ of OM. A few number of striations parallels to the edge are visible in $\mathrm{c} \& \mathrm{~d}$.
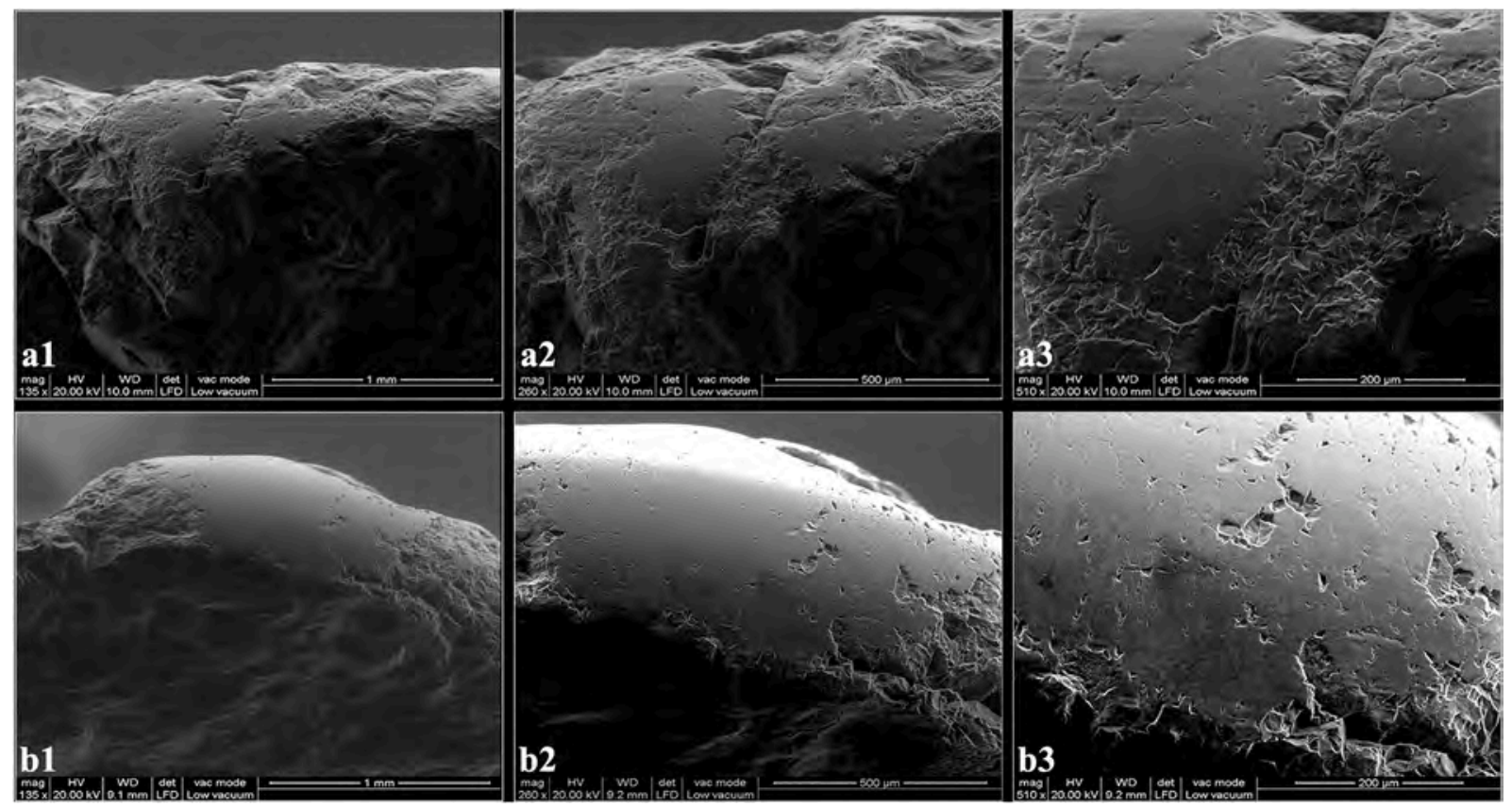

Fig. 7. Well develop micro-polish in a flint experimental tool after $120 \mathrm{~min}$ of use observed under a SEM- Secondary electron detector (LFD). a1 (Original mag. $260 \times$, SEM micrograph), a2 (Original mag. 510 $\times$, SEM micrograph) and a3 (Original mag. $1250 \times$, SEM micrograph) represent the same point with different magnifications. b1 (Original mag. $135 \times$, SEM micrograph), b2 (Original mag. $260 \times$, SEM micrograph) and b3 (Original mag. $510 \times$, SEM micrograph) represent the same point of a micro-polish generated in the protruding part of the flint tool's edge after $120 \mathrm{~min}$ of use. There are some undulated linear features, parallels to the edge, visibles with SEM, but they are difficult to image with OM (a2 \& a3).

\subsubsection{Residues}

Experiments were performed under controlled conditions to avoid any modern contamination (Pedergnana et al., 2016). The documentation of microscopic residues on the lithics was made without further extraction, immediately after the experiments and before any cleaning procedure or storage, as well as the chemical characterization by means of EDX-analysis.

From the first stages of the experiments, limestone generates a large amount of loose powder (Fig. 12f) As tools engrave deeply into the limestone, that white powder was deposited on the used edges, in such an extensive way that it was visible to the naked eye. The powder is distributed on compacted spots on the protruding parts of the edges (Fig. 12a, b, c and d) Under wet conditions, that is when water was added to the limestone to help to produce the engraving, the rock powder turned completely into a smooth paste, and covered the active edges. This paste started to harden after few minutes (visible with digital microscopy and SEM) (Fig. 13: 1, 2, 3). However, powder residues are, apparently, easily removed with water.

Concerning the distribution of remains, powder residues were present on both faces of the active edges of both unretouched flakes and burins, as is common for longitudinal actions. Both flint and quartzite tools had similar residue distributions. Residues were observed within scars and depressions, in such a way that they were only completely removed by using acid solutions $(\mathrm{HCl})$.

Energy dispersive X-rays spectroscopy (EDX) was applied to one quartzite sample to investigate the elemental composition of limestone 


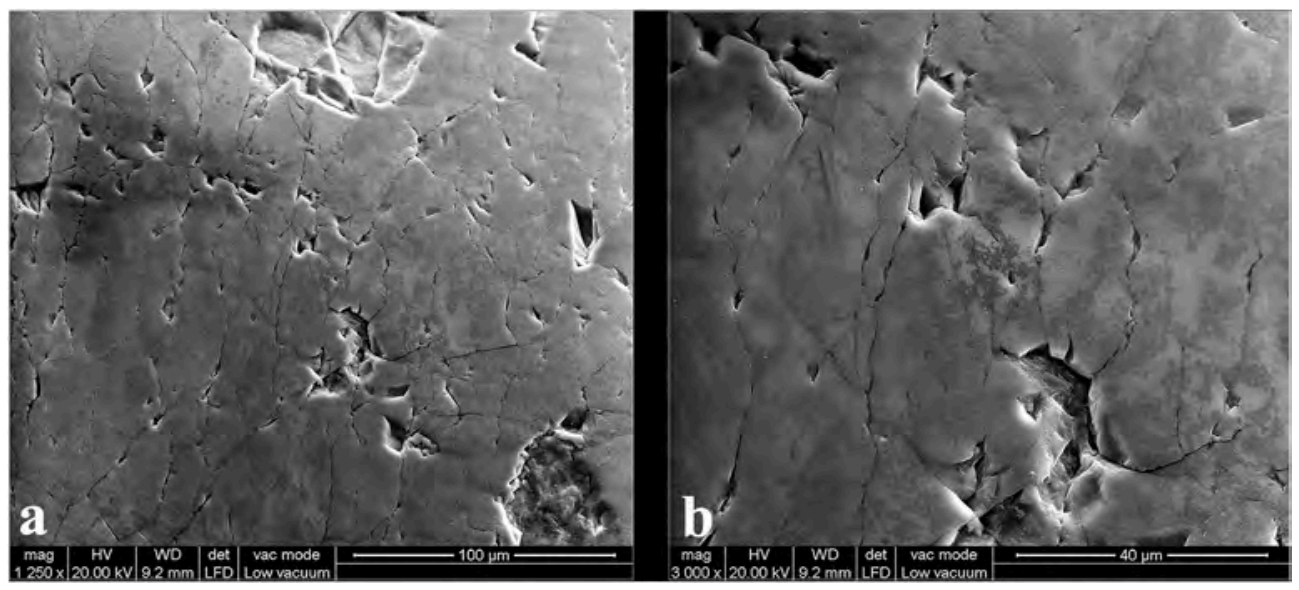

Fig. 8. a (Original mag. $1250 \times$, SEM-LFD micrograph) and b (Original mag. $3000 \times$, SEM-LFD micrograph) represent the same point in a flint piece and show irregular holes on polished areas.

residues. EDX maps showed the presence and distribution of elements. Calcium (Ca) and Carbon (C) (Fig. 13: 6, 7), are connected with the residue, and contrast with the Oxygen (O), Silicon (Si), Aluminium (Al) and Potassium (K) which compose all the rock substrate (Fig. 13: 4, 5, 8, 9).

We are aware that it is necessary to have extraordinarily good preservation conditions to be able to find this kind of residue on archaeological samples. However, with this contribution, we aimed to add a residue type that has not been very well studied to the experimental residue catalogues available in the literature (e.g., Monnier et al., 2012; Rots et al., 2016; Pedergnana and Ollé, 2017).

\section{Discussion}

Since the foundation of use-wear analysis until the present, there have been very few specific experimental studies on stone working. Despite the high probability that there are traces produced by work on stone in sites of different chronologies, it has not been a specific focus of previous studies. In addition, the small number of experimental samples included in the collections of each traceologist (Keeley, 1980; Cahen and Gysels, 1983; Plisson, 1985; Vaughan, 1985; Mansur-Franchomme, 1986; Gijn, 1989; Mazo Pérez, 1989; González Urquijo and Ibáñez Estévez, 1994 ; Clemente Conte, 1997; Astruc, 2002; Fernández-Marchena, 2013; Martín Lerma, 2015; Venditti et al., 2016) and the lack of development of the characterization of this kind of trace make it difficult to compare these data.

Our contribution represents one of the few studies focused exclusively on stone working using two comparable techniques (Alvarez et al., 2001): Optical Light Microscopy and Scanning Electron Microscopy. We included two types of raw materials: quartzite and two varieties of flint. The interest of this work lies in the fact that the experimental studies on quartzite had practically not investigated the traces generated by this kind of activity and in the case of flint, because functional studies have hardly been carried out on these particular varieties (López-Tascón et al., 2018a). Also, the Piloña flint variety has been identified in other archaeological sites within Asturias, as well as beyond, in other regions such as Leon, Cantabria and País Vasco. For this reason, its relevance is not limited to the La Viña rock shelter (Duarte Matías et al., 2016).

The comprehensive study of the surface of our experimental tools has allowed us to identify up to four distinctive groups of use-wear. This reveals the need to be especially aware when referencing prior publications on the subject, which may have identified fewer.

When analysing the use-wear deriving from stone working, rounding is the most frequently observed feature by many analysts. This trait appears quickly on the edges of all experimental tools, except in Martín
Lerma (2015) experimentation, probably because of the low hardness of the schist limestone plaque used as worked material and the short time of use. Well-developed rounding can be considered as a diagnostic trace for stone working. Scarring must be considered as a complementary trace, because it has a high variability and is not always preserved, as rounding may remove scars previously present on edges (Mazo Pérez, 1989; Clemente Conte, 1997; Fernández-Marchena, 2013). The high variability of macro-scars we observed on our experimental samples suggests that they are not diagnostic traces for rock working.

Although there is a consensus with the description of macro-traces, this is not the case of micro use-wear generated during stone working. A careful review of the literature reveals numerous discrepancies with regards to terminology, especially in the terms of micropolish and abrasion. Actually, some of the discrepancies directly stem from the additive or attritional nature of the polished surfaces (Ollé and Vergès, 2008).

Some specialists (Keeley, 1980; Mazo Pérez, 1991) define the micro use-wear generated during stone working as an abrasion, while for other researchers (Gysels and Cahen, 1982; Plisson, 1985; Vaughan, 1985; Mansur-Franchomme, 1986; González Urquijo and Ibáñez Estévez, 1994; Astruc, 2002), it is referred to as a micro-polish. The use of one term or another implies that the researcher considers that the formation processes is different when compared to the formation of other micro-traces by other worked materials.

Plisson (1985), Mansur-Franchomme (1986) and Gysels and Cahen $(1981,1982)$ describe the micropolish as a product of abrasion generated by the friction of stone against stone. Comparably, some technological traces such as linear features found next to both the platform of cores and raw flake edges, have similar characteristics observed on tools used for working limestone. Such lines are generated during knapping and retouching, when hammerstones bear contact with tools. Some particles of the edge are detached and dragged on the surface of the tool, producing these linear features.

However, Keeley (1980: 25), concerning stone polish, stated that "sometimes, spontaneous retouch may be accompanied by a thin band of abrasion on the edge of a flake or blade, which could be mistaken for a "micro-wear polish" when examined at low magnifications. At magnifications of 100x to 200x, it is clear that this "polish" is actually abrasion", establishing a clearly distinction. We are aware that Keeley's work was published some years ago, but, even today, it remains an important reference. In addition, the scarce bibliography on the topic of micropolish resulting from stone working, makes that researchers turn to classic titles, so it is important understand that Keeley's distinctions in terms of terminology were a product of his conception regarding the processes of trace formation.

In light of these results, it is necessary to correctly classify this feature and attempt to use a homogeneous terminology going forward, to avoid 


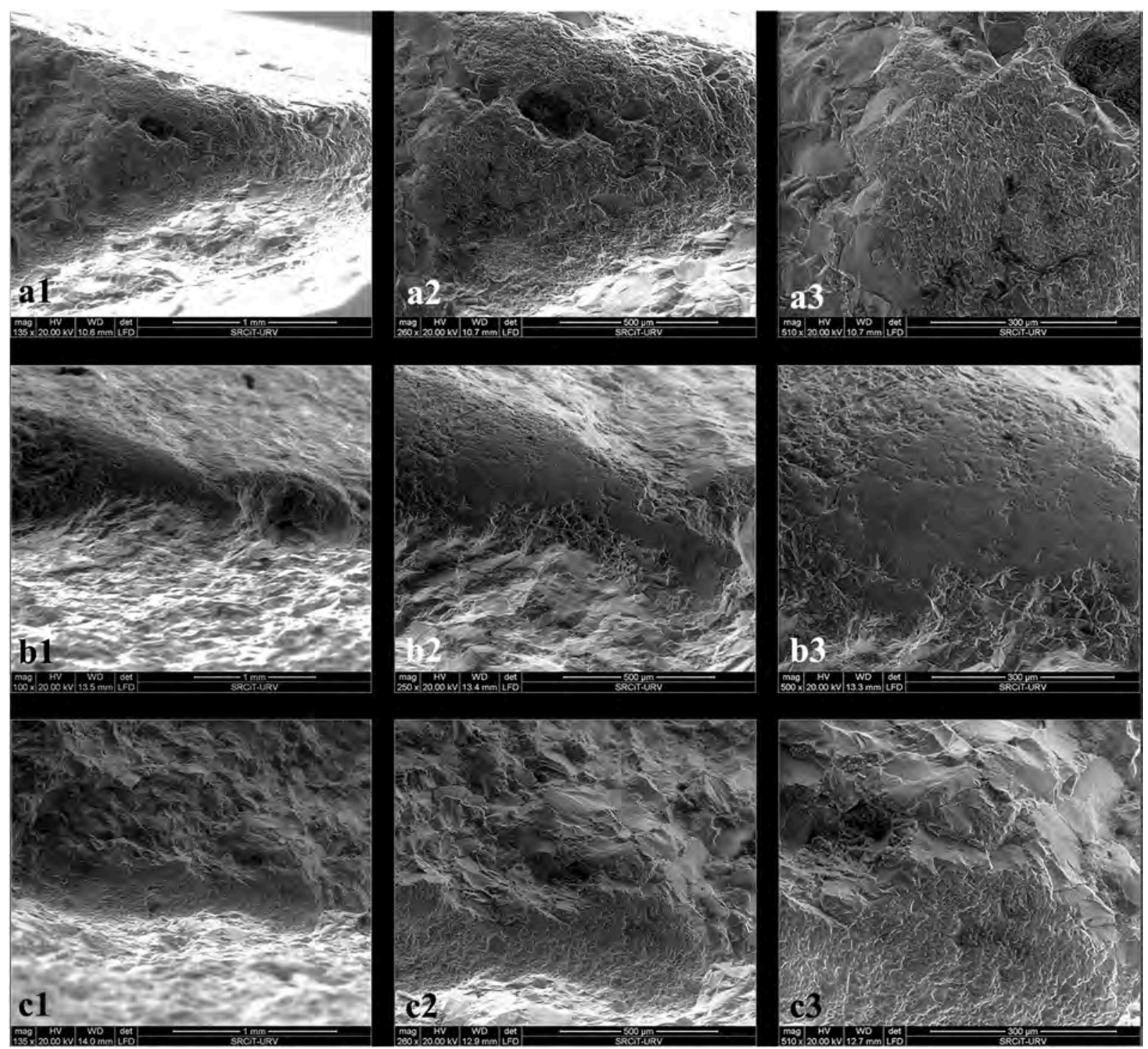

Fig. 9. Examples of different visual appearances of micro-polis on three quartzite tools analysed under SEM-Secondary electron detector (LFD): a1 (Original mag. $135 \times$, SEM micrograph), a2 (Original mag. $280 \times$, SEM micrograph) and a3 (Original mag. $510 \times$, SEM micrograph) represent same point, with a rough and pitted polish. b1 (Original mag. $250 \times$, SEM micrograph), b2 (Original mag. $500 \times$, SEM micrograph) and b3 (Original mag. $1000 \times$, SEM micrograph) represent the same point and show a flat, smooth, non-pitted polish in the centre with a rough polish and pitted around it. c1 (Original mag. $135 \times$, SEM micrograph), c2 (Original mag. $260 \times$, SEM micrograph), c3 (Original mag. $510 \times$, SEM micrograph) represent the same point, with a rough polish concentrated in the high areas of the microtopography.

confusion. We propose that the micro use-wear resulting from stone working should be defined as a micro-polish. More so than simply abrasion, although of course in the formation of such a polish there is an evident attritional process. In other words, the micro trace generated during working stone should be referred to as "micro-polish", while the process involved in the formation of this trace is an "abrasion".

The micro-polish is characterized by being very smooth and flat. Polished surfaces appear totally cracked, with fissures arranged perpendicular to the axis of motion, and resulting from the material fatigue induced by the high pressure against the hard limestone surface. These fissures have never been documented or described in previous works and have probably been confused with striations (Astruc, 2002). In contrast, we only identified some superficial striations and grooves that cover the polished surfaces, that transversally cross the mentioned cracks and indicated the kinematics of the action. Such a well-developed polish is highly diagnostic with three types of microscopy (Figs. 6, 7 and 11), easy to distinguish from other characteristic polished surfaces, as the ones obtained by working other materials (bone, wood, etc.).
Another novel aspect of this work is that limestone residues have been characterized for the first time by elemental (EDX was applied to an experimental sample to determine their elemental composition) and microscopic analyses. The large quantity of powder generated during rock engraving is important for several reasons. In the experimental collection this kind of residue is easily detectable, as its white colour highly contrasts with the black colour of quartzite and flint pieces. However, the colour of the residue is often not visible on the archaeological pieces, due to the lighter colour of the substrate rocks or the whitish colour of the pieces caused by post-depositional conditions.

Also, the limestone powder appears under the $\mathrm{OM}$ as an amorphous accumulation of white particles (Fig. 12f). Its colour and morphological appearance could be mistaken for other residues such as antler and bone (Rots et al., 2016). For this reason, it is useful to recognize residues using OM and SEM, but it is necessary to complement it with chemical analysis (Monnier et al., 2017; Croft et al., 2018). Both SEM-EDX spectra of the residues of antler and bone in experimental tools showing the main peaks of $\mathrm{C}, \mathrm{Ca}, \mathrm{P}, \mathrm{O}$, with minor concentrations of $\mathrm{Na}, \mathrm{Mg}, \mathrm{K}, \mathrm{Mn}$ and Fe 


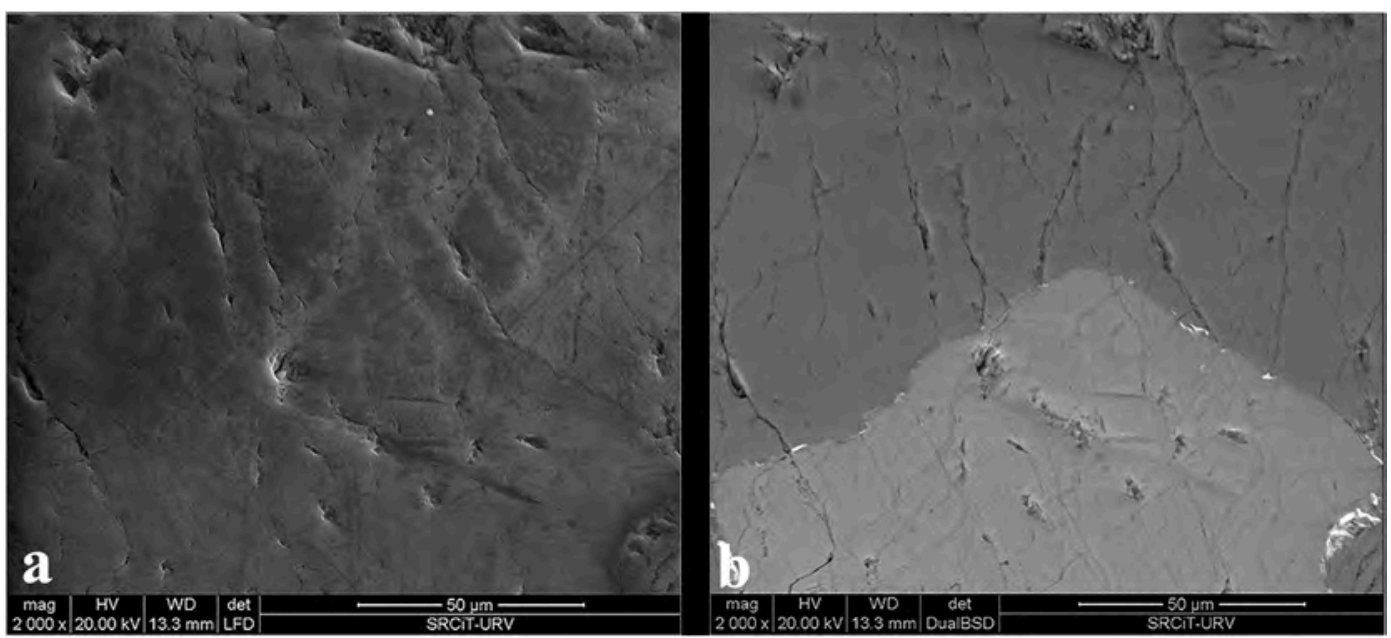

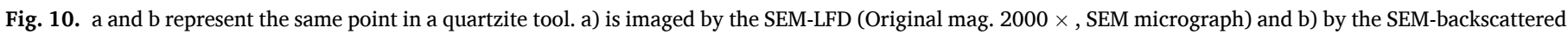
electron detector (BSD) (Original mag. $2000 \times$, SEM micrograph). The crystal of potassium (K) is only visible in the image b and appear in white colour.

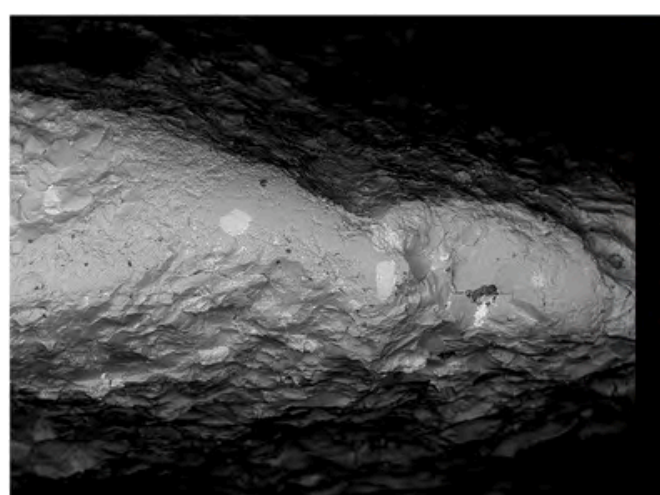

a

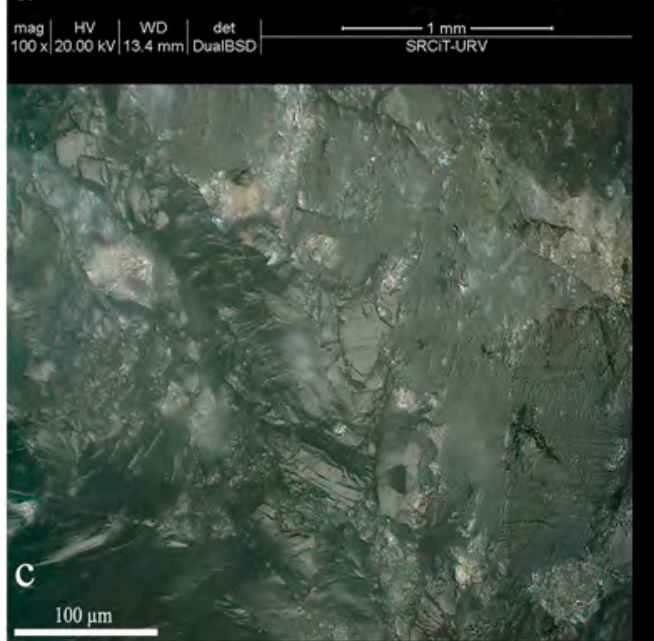

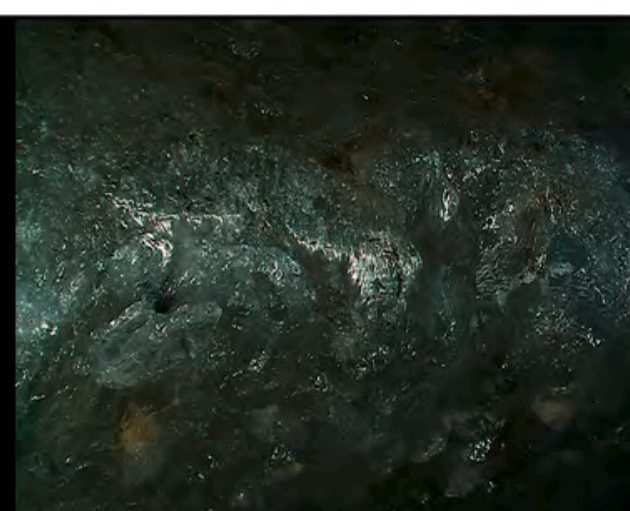

b

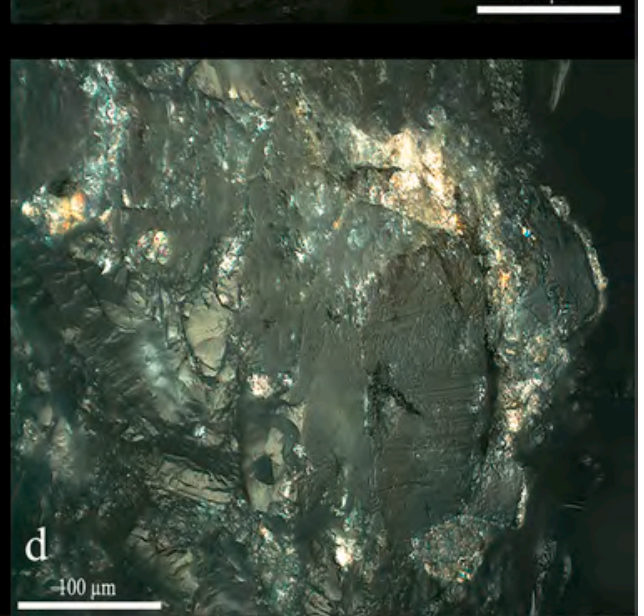

Fig. 11. Comparison of the SEM-BSD image (a) and digital microscopy image (b) in an experimental quartzite tool. a) Original mag. $100 \times$, SEM-BSD micrograph; b) Original mag. $100 \times$, digital microscopy micrograph. c) Original mag. $700 \times$ and d) Original mag. $700 \times$ digital microscopy images, represent the same point with different light. In these images ( $c$ and d), the crystal that contain the element potassium $(\mathrm{K})$, that appear with colour white in image a), present parallel striations to the edge, totally different from the micro polish that it is in. These striations only are visibles under the digital microscopy. (For interpretation of the references to colour in this figure legend, the reader is referred to the Web version of this article.)
(Pedergnana and Ollé, 2017), contrasting with the elements of the limestone residue ( $\mathrm{C}, \mathrm{Ca}, \mathrm{O})$. The EDX analysis also allows to differentiate it from other modern contaminants, such as modelling clay or skin flakes. Modelling clay can appear in a white colour on the surface of lithic artefacts under the OM, but its appearance is darker when observed with SEM detectors (Secondary electron detector and backscattered detector). The EDX spectrum of modelling clay exhibiting the presence of Carbon (C), Sodium (Na), Chlorine $(\mathrm{Cl})$, with minor concentration of Sulphur (S), Potassium (K) and Calcium (Ca), has already been described in another article (Pedergnana et al., 2016), as well as components of skin flakes, (Carbon (C), Sodium (Na), Chlorine (Cl), Sulphur (S), Potassium (K) and Calcium (Ca)). Skin flakes are visible under the OM, being white and birefringent, but under detectors of SEM having generally a dark aspect. Therefore, elemental analyses of those kinds of modern residues show the presence of elements different from those of the limestone residue.

This study is a methodological approach for the analysis of tools used in limestone working and provides a basis for future investigation. While 


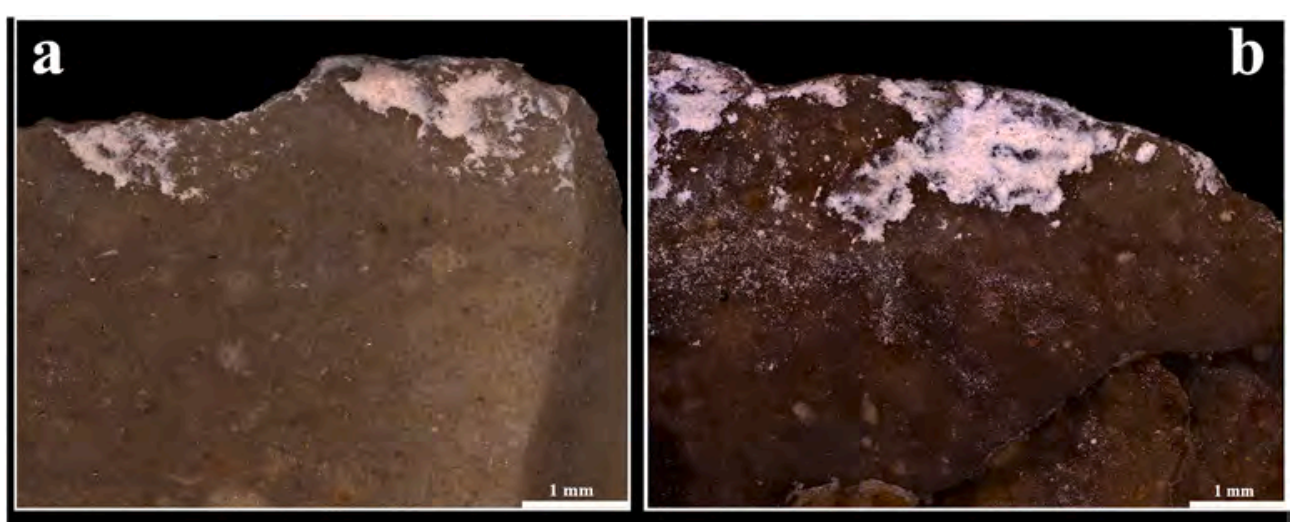

Fig. 12. a) Experimental flint tool with limestone residues in the edge under digital microscopy (Original mag. $100 \times$ ); b) another experimental flint tool with distribution of powder's limestone residues along the edge (Original mag. $100 \times$ ), c) and d) under digital microscopy (Original mag. $100 \times$ ) show the distribution of residues in an experimental quartzite tool before use (c) and after $60 \mathrm{~min}$ of engraving a limestone slab (d); e) a slab of limestone engraved with big quantity of residue generated and a detail of the groove within residue (f).
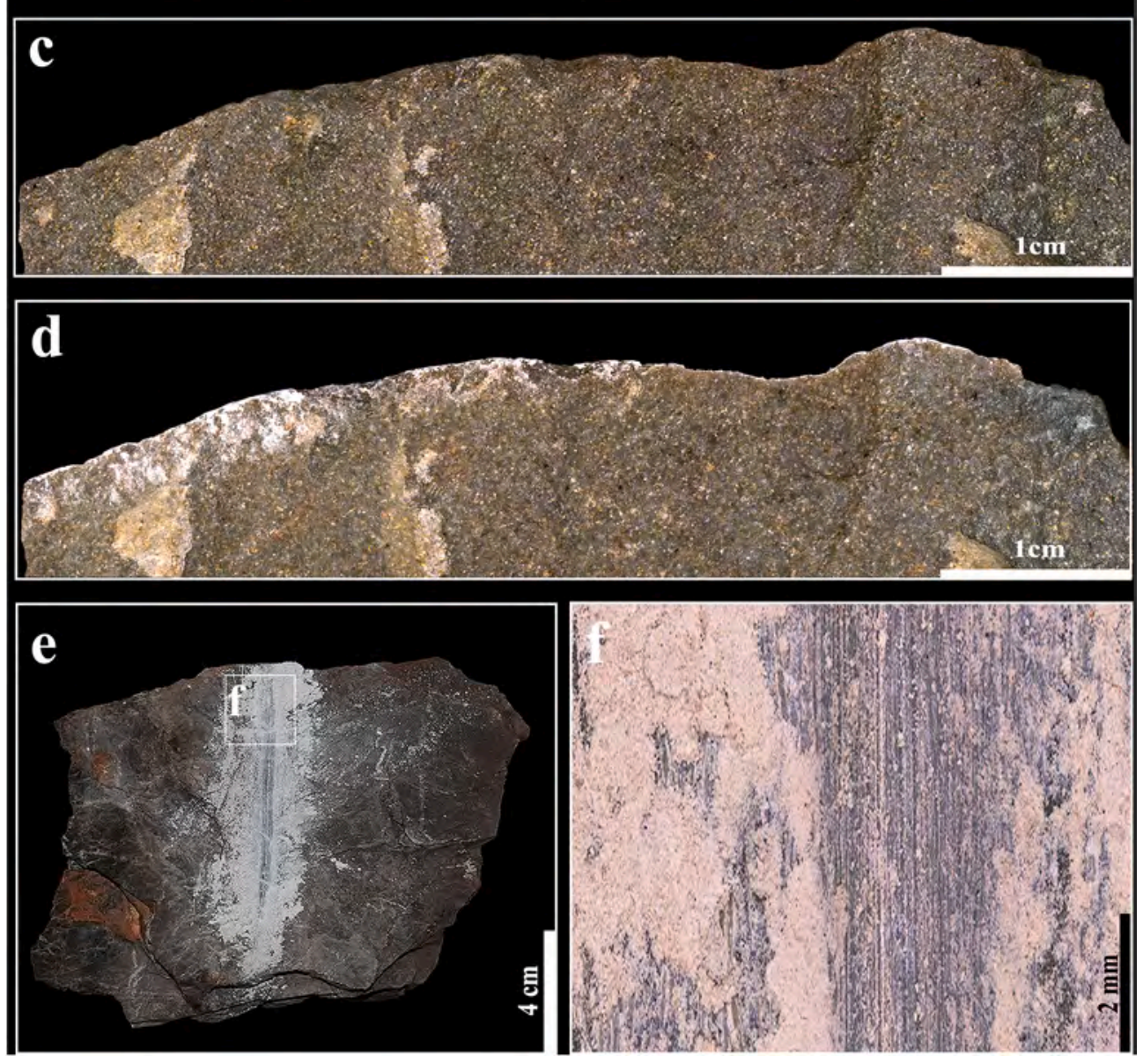

the experimental programme should be extended to include other varieties of flints and quartzites, other controlled experiments must be considered in future research as well. In addition, the application of confocal microscopy (LSCM) as a technique to quantify and characterise micro use-wear would be a great complement to OM and SEM (Álvarez-Fernández et al., 2020; Pedergnana et al., 2020).

Finally, the obvious next step will be the application of these experimental results to identify use-wear traces produced by rock working on the archaeological record of La Viña, but it would also be interesting to examine lithic collections from other rock art sites and compare those with this experimental data.

In this way, our study will contribute to address one of the ongoing great debates: how can engravings be dated? Traditionally, engravings that do not contain any datable materials such as charcoal inside the grooves, have been dated by style and analogy with other engraved motifs, although this sometimes provides wide chronological ranges
(Hernando Álvarez, 2011). To be certain that these types of analyses are correct, the use-wear analysis of the lithic archaeological record should be included in the process of dating art representations. We propose analysing the lithic elements contained in the stratigraphy in conjunction with the artistic elements made on stone from the site, not independently. If the lithic tools associated with stone work derive from a certain archaeological level, the functional analysis could establish a relative dating that complements art studies undertaken previously or in the future. Likewise, if the lithic tools are associated to various levels of the stratigraphy with different chronocultural affiliation, the engravings could have been made at different times during the occupation of the site. Consequently, the obtained use-wear data should be interpreted in conjunction with archaeological and stratigraphic data, as well as the style studies and the calculation of manual range if possible. 


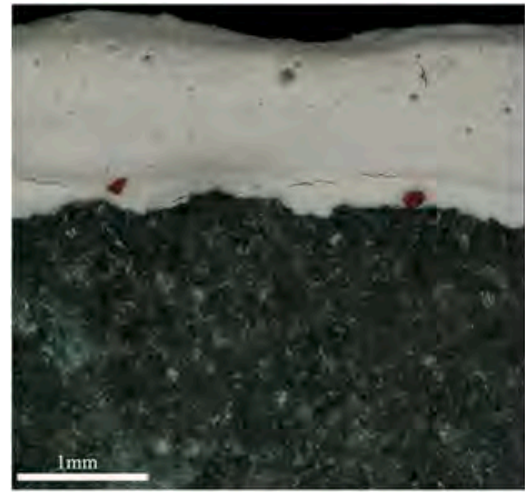

1

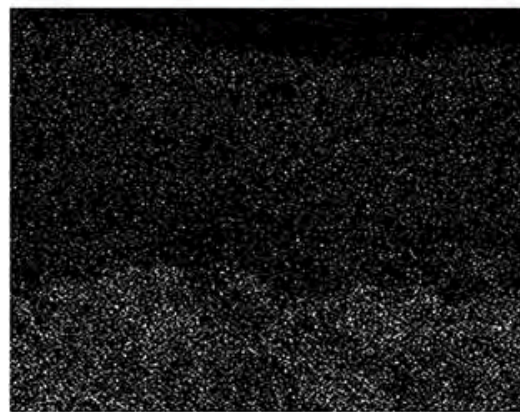

O Ka1

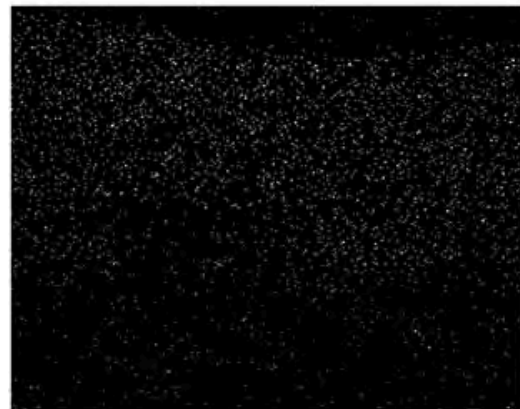

C Kal_2

7

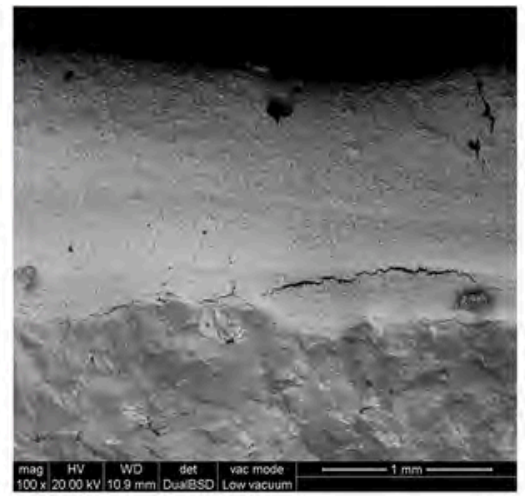

2

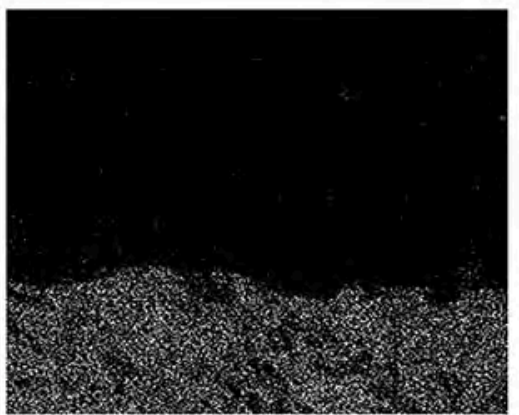

$4 \quad \mathrm{Si} \mathrm{Kal}$

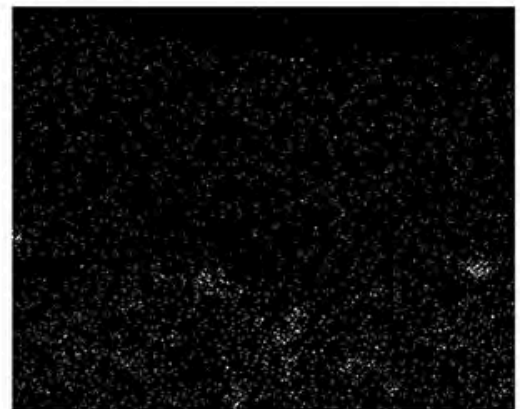

Al Kal

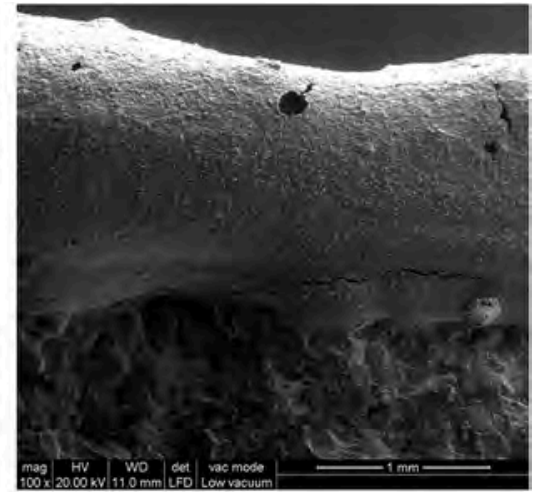

3

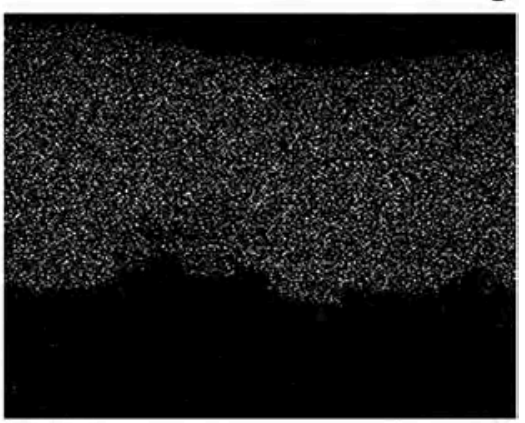

Ca Ka 1

6

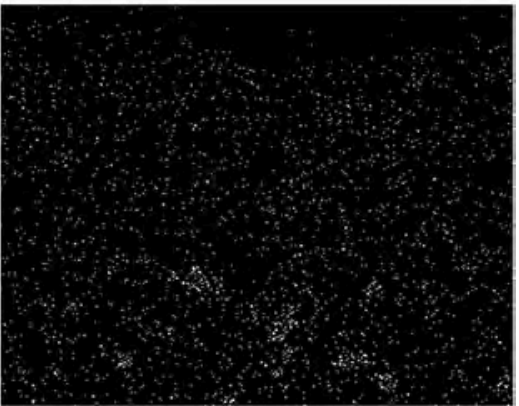

K Kal

Fig. 13. Distribution of experimental limestone residue imaged by the digital microscopy (Original mag. $100 \times$ ) $(1)$, the SEM-backscattered electron detector (Original mag. $100 \times$ ) (2) and the SEM-secondary electron detector (Original mag. $100 \times$ ) (3). 4-9 Mapping of the same residue showing the elements detected through EDX and connected with the residue $(4=\mathrm{O} ; 5=\mathrm{Si} ; 6=\mathrm{Ca} ; 7=\mathrm{C} ; 8=\mathrm{Al} ; 9=\mathrm{K})$.

\section{Conclusions}

This study provided new information about use-wear connected with the parietal engraved art located in the Cantabrian region. The method developed herein could also be applied to other archaeological sites displaying engraved rock art pertaining to diverse geographical regions and chronologies.

According to the results presented here, working limestone with flint and quartzite tools produces particular use-wear traces. The combined use of different microscopes (OM and SEM) was important to image usewear produced by working limestone on both quartzite and flint edges (Borel et al., 2014), although we recognize the need to expand the experimental sample.

In light of these results, the method developed here helps better understand the relationship between engraved walls and human occupation of caves, rock shelters and open-air sites with parietal art. Being able to identify the presence of lithic tools used in the decoration of symbolic places will help in the interpretation of the human behavioural choices and technological strategies of the artists who produced the rock art. These data have the potential to be complementary to information provided by rock art specialists.

\section{Declaration of competing interest}

The authors declare that they have no known competing financial interests or personal relationships that could have appeared to influence the work reported in this paper.

\section{Acknowledgments}

We want to thank M. González-Pumariega, M. Polledo, J. C. Cañaveras and D. Santamaría their advice and suggestions, and T. López for helping with the experimentation. The authors want to thank C. Schwalbe for the English editing of the manuscript. This research is partially framed in the Spanish MICINU-FEDER (PGC2018-093925-BC32), the AGAUR (2017-SGR-1040) and the URV (2019PFR-URV-9.1) projects. We are also grateful to the Servei de Recursos Científics i Tècnics team of the Rovira i Virgili University (Tarragona, Spain). C. López-Tascón is the beneficiary of a Severo Ochoa predoctoral grant from the Principado de Asturias. Finally, we would like to thank the two 
anonymous reviewers and the guest editor L. Asryan for their fruitful comments and suggestions.

\section{Appendix A. Supplementary data}

Supplementary data to this article can be found online at https://doi. org/10.1016/j.quaint.2020.07.012.

\section{References}

Alvarez, M., Fiore, D., Favret, E., Castillo Guerra, R., 2001. The use of lithic artefacts for making rock art engravings: observation and analysis of use-wear traces in experimental tools through optical microscopy and SEM. J. Archaeol. Sci. 28, 457-464. https://doi.org/10.1006/jasc.2000.0571.

Álvarez-Fernández, A., García-González, R., Márquez, B., Carretero, J.M., Arsuaga, J.L., 2020. Butchering or wood? A LSCM analysis to distinguish use-wear on stone tools. J. Archaeol. Sci.: Report 31, 102377. https://doi.org/10.1016/j. jasrep.2020.102377.

Anderson-Gerfaud, P., 1981. Contribution méthodologique a l'analyse des microtraces d'utilisation sur les outils préhistoriques. Université de Bordeaux I. Unpublished Thesis.

Astruc, L., 2002. L'outillage lithique taillé de Khirokitia. Analyse fonctionnelle et spatiale, Monographie du CRA, vol. 25. CNRS.

Aubry, T., Sampaio, J., 2012. Novos dados para a abordagem técnica da arte rupestre móvel do vale do Côa. In: Sánchez, Jesús, Coord, M. de ( (Eds.), I. ${ }^{\mathrm{a}}$ Mesa-Redonda Artes rupestres da Pré-História e da Proto-História: Paradigmas e metodologías de registo, vol. 54. Trabalhos de arqueología, Lisboa, pp. 185-206.

Aubry, T., Sampaio, J., Luís, L., 2011. Approche expérimentale appliquée à l'étude des vestiges du Paléolithique supérieur de la Vallée du Cõa (Portugal). In: Morgado, A., Baena Preysler, J., García González, D. (Eds.), La investigación experimental aplicada a la Arqueología, Tecnología y Traceología lítica prehistórica y su experimentación, vol. 1. Universidad de Granada, Granada, pp. 87-96.

Aubry, T., Santos, A.T., Luís, L., 2014. Stratigraphies du panneau 1 de Fariseu: analyse structurelle d'un système graphique paléolithique à l'air libre de la vallée du Côa (Portugal). In: Paillet, P., Dir (Eds.), Les arts de la Préhistoire: micro-analyses, mise en contextes et conservation. Actes du colloque «Micro-analyses et datations de l'art préhistorique dans son contexte archéologique», MADAPCA - Paris, 16-18 novembre 2011, PALEO, numéro spécial, pp. 259-270.

Beaune, S. A. de, Pinçon, G., 2001. Approche expérimentale des techniques magdaléniennes de sculpture pariétale: le cas d'Angles-sur-1' Anglin (Vienne)". In: Bourguignon, L., Ortega, I., Frère-Sautot, M.-C. (Eds.), Préhistoire et approche expérimentale, Préhistoires 5, Éditions Monique Mergoil, pp. 67-75.

Beltrán Martínez, A., 2002. Art rupestre dans la grotte du Parpalló (Gandía, Valence, Espagne). International Newsletter on Rock Art. Bulletin de l'I.N.O.R.A. 33, 7-11.

Beyries, S., 2008. Modélisation du travail du cuir en ethnologie: proposition d'un système ouvert à l'archéologie. Anthropozoologica 43 (1), 9-42.

Beyries, S., Cattin, M.-I., 2015. Resharpening and recycling: different conceptions of the Magdalenian tools. Quat. Int. 361, 260-268. https://doi.org/10.1016/j. quaint.2014.07.042.

Borel, A., Ollé, A., Vergès, J.M., Sala, R., 2014. Scanning Electron and Optical Light Microscopy: two complementary approaches for the understanding and interpretation of usewear and residues on stone tools. J. Archaeol. Sci. 48, 46-59. https://doi.org/10.1016/j.jas.2013.06.031.

Cahen, D., Gysels, J., 1983. Techniques et fonctions dans l'industrie lithique du groupe de Blicquy (Belgique). In: Traces d'utilisation sur les outils néolithiques du Proche Orient. Table ronde CNRS tenue à Lyon du 8 au 10 juin 1982. Maison de l'Orient et de la Méditerranée Jean Pouilloux, pp. 37-52.

Clemente Conte, I., 1997. Los instrumentos líticos de Túnel VII: una aproximación etnoarqueológica, vol. 2. Treballs d'etnoarqueologia, Madrid.

Clemente Conte, I., Gibaja Bao, J.F., 2009. Formation of use-wear traces in non-flint rocks: the case of quartzite and rhyolite. Differences and similarities. In: Sternke, F., Eigeland, L., Costa, L.-J. (Eds.), Non-Flint Raw Material Use in Prehistory Old prejudices and new directions, XV Congress de l'UISPP, 4-9 septembre 2006, vol. 11. BAR International Series 1939, Lisbon, pp. 93-98.

Croft, S., Chatzipanagis, K., Kröger, R., Milner, N., 2018. Misleading residues on lithics from Star Carr: identification with Raman microspectroscopy. J. Archaeol. Sci.: Report 19, 430-438. https://doi.org/10.1016/j.jasrep.2018.03.018.

Delluc, B., Delluc, G., 1978. Les manifestations graphiques aurignaciennes sur support rocheux des environs des Eyzies (Dordogne). Gall. Prehist. 21 (1-2).

Delluc, B., Delluc, G., Morala, A., Plisson, H., 1988. Quelques objects des grottes de SaintFront de Domme (Dordogne). Bulletin de la Société Historique et Archéologique du Périgord CXV 11-20.

Duarte Matías, E., Rasilla Vives, M. de la, 2020. The bone industry collections from the Middle and Upper Magdalenian levels in La Viña rock shelter and Llonin cave (Asturias, Northern Spain). In: Straus, L.G., Langlais, M. (Eds.), Magdalenian ChronoStratigraphic Correlations and Cultural Connections between Cantabrian Spain and Southwest France.... and beyond. Société Préhistorique Française, Paris, pp. 319-359.

Duarte Matías, E., Santamaría Álvarez, D., Forcelledo Arena, E., Tarriño Vinagre, A., Rasilla Vives, M. de la, 2016. El sílex como recurso mineral en la Prehistoria de Asturias. CPA 26, 157-190.

Fano, M.Á., García-Moreno, A., Corchón-Rodríguez, M.S., Gárate, D., 2018. Patterns in the location of decorated caves: the Nalón river basin (Asturias, North Spain) in premagdalenian times. In: XVIII ${ }^{\circ}$ UISPP World Congress in Paris (4-9 June 2018), Paris
Fernández Rey, A., Adán, G.E., Arbizu, M., Arsuaga, J.L., 2005. Grafismo rupestre paleolítico de la Cueva del Conde (Tuñón, Santo Adriano, Asturias). Zephyrus 58, 67-88.

Fernández-Marchena, J.L., 2013. Análisis funcional de los artefactos en cristal de roca de Cova Eirós. Aproximación experimental, análisis traceológico y de residuos. Universitat Rovira i Virgili, Tarragona, Unpublished Master's Thesis.

Fernández-Marchena, J.L., Ollé, A., 2016. Microscopic analysis of technical and functional traces as a method of the use-wear analysis of rock crystal tools. Quat. Int. 424, 171-190. https://doi.org/10.1016/j.quaint.2015.10.064.

Fernández-Marchena, J.L., Rabuñal, J.R., Mateo-Lomba, P., Lombao, D., Hernando, R., Cueva-Temprana, A., Cazalla, I., 2020. Rainbow in the dark. The identification of diagnostic projectile impact features on rock crystal. J. Archaeol. Sci.: Report 31. https://doi.org/10.1016/j.jasrep.2020.102315.

Fortea, J., 1981. Investigaciones en la cuenca media del Nalón Asturias (España). Noticia y primeros resultados. Zephyrus 32-33, 5-16.

Fortea, J., 1990. Abrigo de La Viña. Informe de las campañas 1980-1986. In: Excavaciones Arqueológicas en Asturias (1983-1986), vol. 1, pp. 55-68.

Fortea, J., 1992. Abrigo de La Viña. Informe de las campañas 1987-1990. In: Excavaciones Arqueológicas en Asturias (1987-1990), vol. 2, pp. 19-28.

Fortea, J., 1994. Los "santuarios" exteriores en el Paleolítico Cantábrico. Complutum 5, 203-220.

Fortea, J., 1995. Abrigo de La Viña Informe y primera valoración de las campañas 1991 1994. In: Excavaciones Arqueológicas en Asturias (1991-1994), vol. 3, pp. 19-32.

Fortea, J., 1999. Abrigo de La Viña. Informe y primera valoración de las campañas de 1995-1998. In: Excavaciones Arqueológicas en Asturias (1995-1998), vol. 4, pp. 31-41.

Fortea, J., 2000-2001. Los comienzos del arte paleolítico en Asturias: aportaciones desde una arqueología contextual no postestilística. Zephyrus 53-54, 177-216.

Fortea, J., 2005-2006. Los grabados exteriores de Santo adriano (Tuñón. Santo adriano. Asturias). Munibe 57, 23-52.

Fortea, J., Rasilla, M. de la, 2000. L’art rupestre paleolític cantàbric: investigació i conservació. Cota Zero 16, 9-23.

Fortea, J., Rodríguez, V., 2007. Los grabados exteriores de la cuenca media del Nalón. In: Rodríguez, J., Coord (Eds.), La Prehistoria en Asturias: un legado artístico único en el mundo. La Nueva España, Oviedo, pp. 167-194.

Fortea, J., Rasilla, M. de la, Santamaría, D., Martínez, L., Duarte, E., Fernández de la Vega, J., 2010. El Paleolítico Superior en Asturias en los albores del siglo XXI. In: Mangado, X. (Ed.), Jornadas Internacionales sobre el Paleolítico Superior Peninsular. Novedades del siglo XXI. Homenaje al Prof. Javier Fortea. SERP, Barcelona, pp. 271-289.

García Díez, M., González Morales, M.R., Strauss, L.G., 2012. El grafismo rupestre paleolítico de la cueva de El Mirón (Ramales de la Victoria, Cantabria, España): una propuesta para su datación estratigráfica. Trab. Prehist. 69 (1), 21-36.

García, A., Fano, M.Á., Garate, D., 2013. Integrating spatial analyses into foraging societies land use strategies. A case study from the Nalón river basin (Asturias, North of Spain). In: Earl, G., Sly, T., Chrysanthi, A., Murrieta-Flores, P., Papadopoulos, C., Romanowska, I., Wheatley, D. (Eds.), Archaeology in the Digital Era. Volume II. EPapers from the 40th Conference on Computer Applications and Quantitative Methods in Archaeology. Southampton, 26-30 March 2012. Amsterdam University Press, Amsterdam, pp. 670-677.

Gavelas, J., 1980. Breves notas sobre el santuario prehistórico del abrigo de la Manzaneda, vol. 101. Boletín del Instituto de Estudios Asturianos, pp. 933-935.

Gijn, A.L. van, 1989. The Wear and Tear of Flint. Principles of Functional Analysis Applied to Dutch Neolithic Assemblages, Analecta Praehistorica Leidensia, vol. 22. University of Leiden, Sidestone Press.

González Urquijo, J.E., Ibáñez Estévez, J.J., 1994. Metodología de análisis funcional de instrumentos tallados en sílex. Universidad de Deusto, Bilbao.

González-Pumariega, M., 2014. El arte rupestre paleolítico del abrigo de La Viña (Oviedo, Asturias). Presentación de su estudio actual dentro del proyecto de investigación del yacimiento. In: Medina-Alcaide, M.A., Romero Alonso, A.J., RuizMárquez, R.M., Sanchidrián Torti, J.L., Coords/ (Eds.), Sobre Rocas Y Huesos: Las Sociedades Prehistóricas Y sus Manifestaciones Plásticas. Fundación Cueva de Nerja, Córdoba, pp. 84-95.

González-Pumariega Solís, M., Rasilla Vives, M. de la, Santamaría Álvarez, D., Duarte Matías, E., Santos Delgado, G., 2014. Relación entre la estratigrafía y los grabados parietales del Primer Horizonte Gráfico del abrigo de la Viña (La Manzaneda, Oviedo, Asturias). In: Corchón, M.S., Menéndez, M. (Eds.), Cien años de arte rupestre paleolítico: centenario del descubrimiento de la cueva de la Peña de Candamo, 19142014. Universidad de Salamanca, Salamanca, pp. 351-357.

González-Pumariega Solís, M., Rasilla Vives, M. de la, Santamaría Álvarez, D., Duarte Matías, E., Santos Delgado, G., 2017. Abrigo de La Viña (La Manzaneda, Oviedo, Asturias). Estudio de sus grabados parietales. Trab. Prehist. 74 (2), 238-256.

González-Pumariega Solís, M., Rasilla Vives, M. de la, Santamaría Álvarez, D., Duarte Matías, E., Santos Delgado, G., 2017. La Viña rock shelter (La Manzaneda, Oviedo, Asturias): Relation between stratigraphy and parietal engravings. Quat. Int. 432 (B), 77-85. https://doi.org/10.1016/j.quaint.2015.07.011.

Guéret, C., Bénard, A., 2017. Fontainebleau rock art (Ile-de-France, France), an exceptional rock art group dated to the Mesolithic? Critical return on the lithic material discovered in three decorated rock shelters. J. Archaeol. Sci. Rep. 13, 99-120. https://doi.org/10.1016/j.jasrep.2017.03.039.

Gutiérrez Sáez, C., 1990. Introducción a las huellas de uso: los resultados de la experimentación. Espacio, Tiempo y Forma, Serie I. Prehistoria y Arqueología t. 3, 15-53.

Gysels, J., Cahen, D., 1981. Premiers résultats de l'analyse des traces microscopiques d'usure de quelques outils de Mesvin IV. Notae Praehistoricae 1, 75-82. 
Gysels, J., Cahen, D., 1982. Le lustre des faucilles et les autres traces d'usage des outils en silex. Bull. Soc. Prehist. Fr. 79, 221-224.

Hernando Álvarez, C., 2011. Nuevas perspectivas de un viejo problema: los grabados exteriores premagdalenienses de la Cornisa Cantábrica. Contexto cronológico y homogeneidad gráfica. Munibe 62, 101-116.

Higham, T., Douka, K., Wood, R., Bronk Ramsey, Ch, Brock, F., Basell, L., Camps, M., Arrizabalaga, A., Baena, J., Barroso-Ruiz, C., Bergman, Ch, Boitard, C., Boscato, P., Caparrós, M., Conard, N.J., Draily, Ch, Froment, A., Gambassini, P., GarcíaMoreno, A., Grimaldi, S., Haesaerts, P., Holt, B., Iriarte-Chiapusso, M.J., Jelinek, A. Jordá, J.F., Maíllo-Fernández, J.M., Marom, A., Maroto, J., Menéndez, M., Metz, L., Morin, E., Moroni, A., Negrino, F., Panagopoulou, E., Peresani, M., Pirson, S., Rasilla, M.de la, Riel-Salvatore, J., Ronchitelli, A., Santamaría, D., Semal, P., Slimak, L., Soler, J., Soler, N., Villaluenga, A., Pinhasi, R., Jacobi, R., 2014. The timing and spatiotemporal patterning of Neandertal disappearance. Nature 512, 306-309. https://doi.org/10.1038/nature13621.

Jardón Giner, P., 1990. La metodología del análisis traceológico y su aplicación a conjuntos líticos prehistóricos. SAGVNTVM 23, 9-37.

Keeley, L.H., 1980. Experimental Determination of Stone Tool Uses. A Microwear Analysis. University of Chicago Press, Chicago.

Leroi-Gourhan, A., Allain, J., 1979. Lascaux inconnu. XIIe Supplément à Gallia préhistoire. CNRS.

López-Tascón, C., Mazo, C., Rasilla, M. de la, 2018. Experimentación y huellas de uso, una relación indisociable: Aplicación de un programa experimental sobre diferentes variedades silíceas. In: Actas de las IX Jornadas de Jóvenes en Investigación Arqueológica, Santander 8-11 junio 2016. Instituto Internacional de Investigaciones Prehistóricas de Cantabria, IIIPC, pp. 119-127.

López-Tascón, C., Rasilla Vives, M. de la, González-Pumariega Solís, M., Santos Delgado, G., Mazo Pérez, C., 2018. Grabando la pared en el abrigo de La Viña (La Manzaneda, Oviedo, Asturias). Programa experimental para el análisis de huellas de uso en industria lítica. Butll. Arqueol. 40, 307-313.

Mansur-Franchomme, M.E., 1986. Microscope du matériel lithique préhistorique. Traces d'utilisation, altérations naturelles, accidentelles et technologiques, vol. 9. Exemples de Patagonie. Cahiers du Quaternaire. CNRS, Paris.

Marín-Arroyo, A.B., Rios-Garaizar, J., Straus, L.G., Jones, J.R., Rasilla, M. de la, González Morales, M.R., Richards, M., Altuna, J., Mariezkurrena, K., 2018. Chronological reassessment of the middle palaeolithic transition in northern Iberia: new dates and revisited sites from the late mousterian to the gravettian. PloS One 13 (4), e0194708. https://doi.org/10.1371/journal.pone.0194708.

Martín Lerma, I., 2015. Funcionalidad de la industria lítica magdaleniense del interior peninsular: La Peña de Estebanvela (Ayllón, Segovia). UNED. Unpublished Thesis.

Martínez Fernández, L., 2015. El Gravetiense en el sector Occidental cantábrico y sus conexiones pirenaicas. Servicio de Publicaciones de la Universidad de Oviedo, Universidad de Oviedo. http://hdl.handle.net/10651/33635.

Martínez Fernández, L., Rasilla Vives, M. de la, 2012. El Gravetiense en Asturias: revisión y novedades. In: Heras Martín, C. de las, Lasheras Corruchaga, J.A., Arrizabalaga Valbuena, Á., Rasilla Vives, M. de la (Eds.), Pensando el Gravetiense. Nuevos datos para la región cantábrica en su contexto peninsular y pirenaico. Ministerio de Educación, Cultura y Deporte, España, pp. 276-288.

Martínez-Cuesta, R., Gutiérrez-Zugasti, I., Rigaud, S., Rasilla Vives, M. de la, 2018. Shell ornaments from the Aurignacian and Gravettian levels at La Viña rockshelter (Asturias, northern Iberia): a technological and functional approach. In: XVIII UISPP World Congress in Paris (4-9 June 2018), Paris.

Mazo Pérez, C., 1989. Análisis de huellas de uso en útiles de sílex del Paleolítico: Aplicación del método al estudio del nivel magdaleniense de Abauntz (Arraiz, Navarra). Universidad de Zaragoza. Unpublished Thesis.

Mazo Pérez, C., 1991. Glosario y cuerpo bibliográfico de los estudios funcionales en Prehistoria, Monografías Arqueológicas, vol. 34. Universidad de Zaragoza, Zaragoza.

Mazzuco, N., Clemente, I., Gassiot, E., Gibaja Bao, J.F., 2015. Insights into the economic organization of the first agro-pastoral communities of the NE of the Iberian Peninsula: a traceological analysis of the Cueva de Chaves flaked stone assemblage. J. Archaeol. Sci. Rep. 2, 353-366. https://doi.org/10.1016/j.jasrep.2015.02.010.

Medina-Alcaide, M, A., Romero, A.J., Peña Villaverde, J.A., Perales Barrón, U., RuizMárquez, R. Mª , Sanchidrián, J.L., 2013. Descifrando la frecuentación paleolítica de Cueva de Nerja. Ejemplo de estudio arqueológico interdisciplinar. In: MedinaAlcaide, Ma, A., Romero, A.J., Coords (Eds.), Mensajes desde el Pasado, Córdoba, pp. 63-68.

Monnier, G.F., Ladwig, J.L., Porter, S.T., 2012. Swept under the rug: the problem of unacknowledged ambiguity in lithic residue identification. J. of Archaeol. Science 39, 3284-3300.

Monnier, G., Frahm, E., Luo, B., Missal, K., 2017. Developing FTIR microspectroscopy for analysis of plant residues on stone tools. J. Archaeol. Sci. 78, 158-178. https://doi. org/10.1016/j.jas.2016.12.004.

Moure Romanillo, A., González Morales, M.R., 1988. El contexto del arte parietal. La tecnología de los artistas en la Cueva de Tito Bustillo (Asturias). Trab. Prehist. 45 $19-49$.

Odell, G.H., Odell-Vereecken, F., 1980. Verifying the reliability of lithic use-wear assessments by "blind tests": the low-power approach. J. Field Archaeol. 7, 87-120.

Ollé, A., Vergès, J.M., 2008. SEM functional analysis and the mechanism of microwear formation. In: Longo, L., Skakun, N. (Eds.), 'Prehistoric Technology' 40 Years Later: Functional Studies and the Russian Legacy, Proceedings of the International Congress Verona (Italy), 20-23 April 2005, BAR International Series, vol. 1783. Archaeopress, Oxford, pp. 39-49.

Ollé, A., Vergès, J.M., 2014. The use of sequential experiments and SEM in documenting stone tool microwear. J. Archaeol. Sci. 48, 60-72. https://doi.org/10.1016/j. jas.2013.10.028.
Pedergnana, A., Ollé, A., 2017. Monitoring and interpreting the use-wear formation processes on quartzite flakes through sequential experiments. Quat. Int. 427, 35-65. https://doi.org/10.1016/j.quaint.2016.01.053.

Pedergnana, A., Asryan, L., Fernández-Marchena, J.L., Ollé, A., 2016. Modern contaminants affecting microscopic residue analysis on stone tools: a word of caution. Micron 86, 1-21. https://doi.org/10.1016/j.micron.2016.04.003.

Pedergnana, A., García-Antón, M.D., Ollé, A., 2017. Structural study of two quartzite varieties from the Utrillas facies formation (Olmos de Atapuerca, Burgos, Spain): from a petrographic characterisation to a functional analysis design. Quat. Int. 433, 163-178. https://doi.org/10.1016/j.quaint.2015.06.031.

Pedergnana, A., Ollé, A., Evans, A.A., 2020. A new combined approach using confocal and scanning electron microscopy to image surface modifications on quartzite. J. Archaeol. Sci.: Report 30. https://doi.org/10.1016/j.jasrep.2020.102237.

Perales, U., Prieto, A., 2015. Industria lítica. In: García-Díez, M., Ochoa, B., Rodríguez Asensio, J.A. (Eds.), Arte rupestre paleolítico en la cueva de la Covaciella (Inguanzo, Asturias), Consejería de Educación, Cultura y Deporte y GEA. Gobierno del Principado de Asturias, pp. 45-49.

Pérez-Estaún, A., Bea, F., 2004. Macizo Ibérico. In: Vera, J.A. (Ed.), Geología de España. SGE-IGME, Madrid, pp. 19-230.

Plisson, H., 1985. Étude fonctionnelle d'outillages lithiques préhistoriques par l'analyse des micro-usures: recherche méthodologique et archéologique. Université de Paris I. Unpublished Thesis.

Plisson, H., 2005. Examen tracéologique de quelques silex collectés sur le sol de la grotte Chauvet. Bull. Soc. Prehist. Fr. 102 (1), 145-148.

Plisson, H., 2007. La fonction des outils de silex dans les grottes ornées paléolithiques. In: Évin, J., Dir (Eds.), Congrès du Centenaire: Un siècle de construction du discours scientifique en Préhistoire, vol. 3. Société Préhistorique Française, Paris, pp. 125-132.

Plisson, H., 2009. Analyse tracéologique de 4 pics d'Olga Grande: des outils pour les gravures de plein air?. In: Aubry, T., Dir (Eds.), 200 séculos da história do Vale do Côa: incursões na vida quotidiana do caçadores-artistas do Paleolítico, vol. 52. Instituto Português de Arqueologia, Trabalhos de Arqueologia, Lisboa, pp. 436-442.

Plisson, H., Zotkina, L.V., 2015. From 2D to 3D at macro- and microscopic scale in rock art studies. Digital Applications in Archaeology and Cultural Heritage 2, 102-119. https://doi.org/10.1016/j.daach.2015.06.002.

Rasilla, M. de la, Duarte, E., Cañaveras, J.C., Santos, G., Carrión, Y., Tormo, C., SánchezMoral, S., Marín-Arroyo, A.B., Jones, J., Agudo, L., Gutiérrez-Zugasti, I., Suárez, P., López-Tascón, C., González-Pumariega, M., 2018. El abrigo de La Viña (La Manzaneda, Oviedo) 2013-2016. Excavaciones Arqueológicas en Asturias 2013-2016 8, 107-120.

Rasilla, M. de la, Duarte, E., Cañaveras, J.C., Sanchis, A., Marín-Arroyo, A.B., Carrión, Y., Real, C., Tormo, C., Sánchez-Moral, S., Gutiérrez-Zugasti, I., Martínez-Cuesta, R., Sauqué, V., Jones, J.R., Agudo, L., Badal, E., Pérez Ripoll, M., Santos, G., 2020. Environment and subsistence strategies at La Viña rock shelter and Llonin cave (Asturias. Spain) during MIS3. J. Archaeol. Sci. Reports 30, 319-358.

Rasilla Vives, M. de la, Rodríguez Otero, V., Santamaría Álvarez, D., Fortea Pérez, J., 2010. Los grabados parietales paleolíticos del Abrigo de Cueto de la Mina (Posada de Llanes, Asturias). Munibe 61, 29-42.

Rios-Garaizar, J., Perales, U., Bourrillon, R., Jiménez-Mena, J., Garate-Maidagan, D. Medina-Alcaide, M.A., 2015. Expresión artística parietal y registro arqueológico discreto en el interior de las cuevas paleolíticas: análisis de huellas de uso de los conjuntos líticos de Nerja y de Etxeberri. In: Garate Maidagan, D., MedinaAlcaide, M.Á., Ruiz-Redondo, A., Sanchidrián Torti, J.L., Coords (Eds.), Entorno a arte: El contexto arqueológico interno de las cuevas decoradas, ARKEOS 37, XIX International Rock Art Conference IFRAO 2015, pp. 489-494 (Cáceres, Spain, 31 August- 4 September 2015).

Ripoll, S., Muñoz, F.J., Avezuela, B., 2007. Sobre la experimentación del bajorrelieve ligero en el arte rupestre: el caso de Church Hole en Creswell Crags (Reino Unido). In: Ramos Sainz, M.L., González Urquijo, J.E., Preysler, Baena, (Coords), J. (Eds.), Arqueología experimental en la Península Ibérica: investigación, didáctica y patrimonio. Congreso Español de Arqueología Experimental, Santander, pp. 165-171, 2005.

Ripoll López, S., Muñoz Ibáñez, F.J., Jordá Pardo, J.F., Martín Lerma, I., 2012. El arte rupestre paleolítico de la cueva de Ambrosio (Vélez-Blanco, Almería, España). Una visión veinte años después. Espacio, Tiempo y Forma, Serie I, Nueva época. Prehistoria y Arqueología 5, 75-97.

Rivero, O., Ruiz-López, J.F., Intxaurbe, I., Salazar, S., Garate, D., 2019. On the limits of 3D capture: a new method to approach the photogrammetric recording of Palaeolithic thin incised engravings in Atxurra Cave (northern Spain). Digital Applications in Archaeology and Cultural Heritage 14, e00106. https://doi.org/ 10.1016/j.daach.2019.e00106.

Rots, V., 2010. Prehension and Hafting Traces on Flint Tools. A Methodology. Leuven University Press.

Rots, V., Hayes, E., Cnuts, D., Lepers, C., Fullagar, R., 2016. Making sense of residues on flaked stone artefacts: Learning from blind tests. PloS One 11 (3), e0150437. https:// doi.org/10.1371/journal.pone.0150437.

Sánchez de la Torre, I., Agueda Villar, J.A., Colmenero Navarro, J., García-Ramos, J.C., González Lastra, J., 1983. Evolución sedimentaria y paleogeográfica del Carbonífero en la Cordillera Cantábrica. In: Martínez Díaz, C. (Ed.), Carbonífero y Pérmico de España. Ministerio de Industria y Energía. Secretaria de la Energía y Recursos Minerales. Instituto Geológico y Minero de España, pp. 133-150.

Santamaría, D., 2012. La transición del Paleolítico Medio al Superior en Asturias. El abrigo de La Viña (La Manzaneda, Oviedo) y la Cueva de El Sidrón (Borines, Pilona). Servicio de Publicaciones de la Universidad de Oviedo, Universidad de Oviedo. http ://hdl.handle.net/10651/19328. 
Santamaría, D., Duarte, E., González-Pumariega, M., Martínez, L., Suárez, P., Fernández de la Vega, J., Santos, G., Higham, T., Wood, R., Rasilla, M. de la, 2014. La Viña rock shelter. In: Sala Ramos, R., Carbonell, E., Bermúdez de Castro, J.M., Arsuaga, J.L., Coords (Eds.), Los cazadores recolectores del Pleistoceno y del Holoceno en Iberia y el estrecho de Gibraltar. Estado actual del conocimiento del registro arqueológico. Universidad de Burgos, Fundación Atapuerca, pp. 95-99.

Sauvet, G., Coords./, 2015. Du bon usage des comparaisons dans l'art rupestre: le cas des signes. In: Medina-Alcaide, M.-A., Romero Alonso, A.J., Ruiz-Márquez, R.M., Sanchidrián Torti, J.L. (Eds.), Sobre Rocas Y Huesos: Las Sociedades Prehistóricas Y sus Manifestaciones Plásticas. Fundación Cueva de Nerja, Córdoba, pp. 14-25.

Semenov, S.A., 1964. Prehistoric Technology; an Experimental Study of the Oldest Tools and Artefacts from Traces of Manufacture and Wear. Translated and with a Pref. By M.W. Thompson, Cory. Adams and Mackay, London.

Suárez Ferruelo, P., 2011. Definición tecno-tipológica y funcional de las laminillas Dufour: el caso de los niveles IX y VIII del Sector Central del Abrigo de La Viña (La Manzaneda, Oviedo, Asturias). CKQ Estudios de Cuaternario 3, 101-121.

Sussman, C., 1986. Functional Studies of Experimental Quartz Artefacts Using Microscopic Analysis of Use-Wear and Polish Formation. UMI's Dissertation Information Service, Universidad de California.

Tarriño Vinagre, A., Duarte Matías, E., Santamaría Álvarez, D., Martínez Fernández, l., Fernández de la Vega Medina, J., Suárez Ferruelo, P., Rodríguez Otero, V., Forcelledo Arena, E., Rasilla Vives, M. de la, 2013. El Sílex de Piloña. Caracterización de una nueva fuente de materia prima en la Prehistoria de Asturias. In: Vives, Rasilla, de la (Coord, M. (Eds.), F. Javier Fortea Pérez. Universitatis Ovetensis Magister. Estudios en Homenaje. Ediciones de la Universidad de Oviedo y Ménsula Ediciones, Oviedo, pp. 115-132.

Tringham, R., Cooper, G., Odell, G., Voytek, B., Whitman, A., 1974. Experimentation in the formation of edge damage: a new approach to lithic analysis. J. Field Archaeol. 1, 171-196. https://doi.org/10.1179/jfa.1974.1.1-2.171.
Vaughan, P.C., 1985. Use-wear Analysis of Flaked Stone Tools. The University of Arizona Press.

Venditti, F., Lemorini, C., Bordigoni, M., Zampetti, D., Amore, M., Tagliacozzo, A., 2016. The role of burins and their relationship with art through trace analysis at the Upper Palaeolithic site of Polesini cave (Latium, Italy). Origini XXXIX (1), 7-30.

Vergès, J.M., Morales, J.I., 2014. The gigapixel image concept for graphic SEM documentation. Applications in archeological use-wear studies. Micron 65, 15-19. https://doi.org/10.1016/j.micron.2014.04.009.

Villa, E., Sánchez de Posada, L.C., 2009. Carboniferous of the cantabrian zone. In: GarcíaCortés, A. (Ed.), Spanish Geological Frameworks and Geosites. An Approach to Spanish Geological Heritage of International Relevance. IGME, Madrid, pp. 44-55.

Villaverde Bonilla, V., 2005. Arte mueble paleolítico en el Mediterráneo Occidental: contexto y diversidad regional. In: Arias Cabal, P., Ontañón Peredo, R. (Eds.), La materia del lenguaje prehistórico. El arte mueble paleolítico de Cantabria en su contexto. Universidad de Cantabria, pp. 67-84.

Wadley, L., 2005. Putting ochre to the test: replication studies of adhesives that may have been used for hafting tools in the Middle Stone Age. J. Hum. Evol. 49, 587-601. https://doi.org/10.1016/j.jhevol.2005.06.007.

Wood, R.E., Arrizabalaga, A., Camps, M., Fallon, S., Iriarte-Chiapusso, M.-J., Jones, R. Maroto, J., Rasilla, M. de la, Santamaría, D., Soler, J., Soler, N., Villaluenga, A., Higham, T.F.G., 2014. The chronology of the earliest upper palaeolithic in northern Iberia: new insights from L'arbreda, Labeko Koba and La Viña. J. Hum. Evol. 69, 91-109. https://doi.org/10.1016/j.jhevol.2013.12.017.

Yamada, S., 1993. The formation process of "Use-wear Polishes". In: Anderson, P. Beyries, S., Otte, M., Plisson, H. (Eds.), Traces et fonction: les gestes retrouvés. Volume II, Actes du colloque international de Liège, 8-10 décembre 1990, vol. 50. CNRS, ERAUL, Liège, pp. 433-444. 